\title{
Gene Action for Various Grain and Fodder Quality Traits in Zea Mays
}

\author{
Qurban Ali ${ }^{1,2}$, Arfan Ali, ${ }^{2, *}$ Muhammad Tariq ${ }^{2}$, Malik Adil abbas $^{2}$, Bilal Sarwar $^{2}$, Mukhtar Ahmad $^{2}$, \\ Mudassar Fareed Awaan', Shafique Ahmed², Zaheer Ahmad Nazar', Faheem Akram², Atif Shahzad², \\ Tahir Rehman Samiullah², Idrees Ahmad Nasir ${ }^{2}$, Tayyab Husnain ${ }^{2}$ \\ ${ }^{1}$ Department of Plant Breeding and Genetics, University of Agriculture Faisalabad, Pakistan \\ ${ }^{2}$ Centre of Excellence in Molecular Biology, University of the Punjab, Lahore Pakistan \\ *Corresponding author: arfan.ali@cemb.edu.pk
}

Received September 09, 2014; Revised September 24, 2014; Accepted September 29, 2014

\begin{abstract}
A Zea may is an important cereal crop. To nourish human and livestock, it is very important that the quality of maize grain and fodder must be higher. A study was conducted to evaluate maize accessions for grain and fodder quality traits. Results indicated that higher heritability was found for nutrient detergent fiber, fodder cellulose, fodder crude fiber, fodder crude and fodder moisture percentage while genetic advance was higher for fodder cellulose, fodder crude protein and fodder ash percentage. High significant genotypic and phenotypic correlation was found among grain protein, oil and starch percentage, nutrient detergent fiber, fodder cellulose, fodder crude fiber \& protein and fodder moisture percentage. The higher cumulative additive effect was recorded for acid detergent fiber, fodder crude fiber; nutrient detergent fiber and fodder cellulose suggested that selections may be made to develop synthetic varieties for better quality. Higher dominance effect and degree of dominance indicated that selection may be useful for the development of good quality maize hybrids through heterosis breeding programme. Principle component bi-plot analysis indicated that B-11×EV-347, B-11, Sh-139, EV-1097×E-322, Sh-139×B-316, B-327×E322, B-316, Raka-poshi, B-11 $\times$ Pop/209, B-336 $\times$ EV-340, B-327×E-322, B-327×F-96, EV-1097×E-322, Rakaposhi $\times$ EV-347, EV-1097×Pop/209 and EV-1097×EV-340 performed better for grain and fodder quality and may be used for improvement of grain and fodder quality of maize.
\end{abstract}

Keywords: zea mays, additive, dominance, degree of dominance, genetic advance, quality

Cite This Article: Qurban Ali, Arfan Ali, Muhammad Tariq, Malik Adil abbas, Bilal Sarwar, Mukhtar Ahmad, Mudassar Fareed Awaan, Shafique Ahmed, Zaheer Ahmad Nazar, Faheem Akram, Atif Shahzad, Tahir Rehman Samiullah, Idrees Ahmad Nasir, and Tayyab Husnain, "Gene Action for Various Grain and Fodder Quality Traits in Zea Mays.” Journal of Food and Nutrition Research, vol. 2, no. 10 (2014): 704-717. doi: 10.12691/jfnr-2-10-9.

\section{Introduction}

Maize (Zea mays L.) plant has a remarkable productive potential and world's leading cereal food crop with added importance for countries like Pakistan where quickly increasing population has already facing less availability of food supplies. Maize is the third important cereal crop in Pakistan than wheat and rice. Maize accounts for 5.67\% of the value of agriculture output. It accounts for 1083 thousands hectares of total cropped area in Pakistan with annual production of 4271 thousand tons. Maize is the dual purpose cereal crop as used in human food, livestock feed and industrial raw material for the manufacturing of various by-products. It has highest crude protein $9.9 \%$ at early and at full bloom stages which decreases to $7 \%$ at milk stage and to $6 \%$ at maturity. Maize has highly nutritive value as it contains $72 \%$ starch, $10 \%$ protein, $4.80 \%$ oil, $9.50 \%$ fiber, $3.0 \%$ sugar, $1.70 \%$ ash, $82 \%$ endosperm, $12 \%$ embryo, $5 \%$ bran testa and $1 \%$ tip cap [1].
Pakistan have livestock population of 154.7 million heads which produce about 43.562 million tons of milk, 1.601 million tons of beef and 0.590 million tons of mutton. The livestock sector of Pakistan contributes about $53.2 \%$ of the agriculture outputs and $11.4 \%$ to national GDP of Pakistan. Green fodder is the most cheapest and precious source for livestock food. It is rich an important source of $35-40 \%$ cellulose, $25.28 \%$ hemicelluloses, $0.30 \%$ fat, $28.70 \%$ crude fiber, $37.22 \%$ acid detergent fiber, $70.85 \%$ neutral detergent fiber, $40.6 \%$ dry matter, $4 \%$ ash, $48.86 \%$ carbohydrates, $9.22 \%$ moisture, $2.84 \%$ ether extract and $11 \%$ crude proteins [1]. The milk production of livestock animals may be increased up to $100 \%$ by using good quality and highly nutritive fodder $[1,2]$. Around $80-90 \%$ of nutrient requirements of livestock are met from the fodder crops but the present fodder supply is $1 / 3$ times less than the actual needs and the majority of the animals remain under fed especially during June-July (extremely hot season) and DecemberJanuary (extremely cold season).

In Pakistan out of total cropped area of 23.51 million ha only 2.46 million ha was under fodder crops with total 
fodder production of 55.06 million tons [3] that is not sufficient enough to fulfill the requirements of nutrition for the existing livestock. The livestock feed pool in Pakistan is deficient by $21 \%$ of total dry matter (DM), and by $33 \%$ of crude protein requirements [2]. The poor yield is due to growing pressure of human population, less and irregular rainfalls, scarcity of irrigation water, less priorities for fodder crop production and imbalance use of fertilizers $[4,5,6]$. Present study was conducted to evaluate maize inbred lines and $F_{1}$ hybrids for various grain and fodder quality traits. Gene action provides plant breeder a plate form to select genotypes with better grain yield and quality [1,7-15].

\section{Materials and methods}

The present study was carried out in the research area of the Department of Plant Breeding and Genetics, University of Agriculture, Faisalabad Pakistan to evaluate the selected maize parents and $F_{1}$ hybrids for grain and fodder quality traits at maturity during crop growing season 2012. The samples were collected from the field at anthesis stage and various quality traits were recorded (AOAC, 1996) in the Animal Nutrition Laboratory, Institute of Animal Nutrition University of Agriculture Faisalabad.

Parents and $F_{1}$ crosses used in evaluation experiment

\begin{tabular}{|c|c|c|c|c|c|}
\hline Sr. No. & Genotypes & Sr. No. & Genotypes & Sr. No. & Genotypes \\
\hline 1 & Pop/209 & 17 & B-11×F-96 & 33 & B-327×EV-340 \\
\hline 2 & B-316 & 18 & B-11×EV-347 & 34 & B-327×E-322 \\
\hline 3 & EV-340 & 19 & B-336×Pop/209 & 35 & B-327×F-96 \\
\hline 4 & E-322 & 20 & B-336 $\times$ B-316 & 36 & B-327×EV-347 \\
\hline 5 & F-96 & 21 & B-336 $\times E V-340$ & 37 & Raka-poshi $\times$ Pop/209 \\
\hline 6 & EV-347 & 22 & B-336 $\times$ E-322 & 38 & Raka-poshi×B-316 \\
\hline 7 & B-11 & 23 & B-336×F-96 & 39 & Raka-poshi $\times E V-340$ \\
\hline 8 & B-336 & 24 & B-336 $\times E V-347$ & 40 & Raka-poshi $\times$ E-322 \\
\hline 9 & EV-1097 & 25 & EV-1097×Pop/209 & 41 & Raka-poshi $\times$ F-96 \\
\hline 10 & B-327 & 26 & EV-1097×B-316 & 42 & Raka-poshi $\times E V-347$ \\
\hline 11 & Raka-poshi & 27 & EV-1097×EV-340 & 43 & Sh-139×Pop/209 \\
\hline 12 & Sh-139 & 28 & EV-1097×E-322 & 44 & Sh-139×B-316 \\
\hline 13 & B-11×Pop/209 & 29 & EV-1097×F-96 & 45 & Sh-139×EV-340 \\
\hline 14 & B-11×B-316 & 30 & EV-1097×EV-347 & 46 & Sh-139×E-322 \\
\hline 15 & B-11×EV-340 & 31 & B-327×Pop/209 & 47 & Sh-139×F-96 \\
\hline 16 & B-11×E-322 & 32 & B-327×B-316 & 48 & Sh-139×EV-347 \\
\hline
\end{tabular}

The seed of $\mathrm{F}_{1}$ hybrids along with their parents were sown in field following a triplicated randomized complete block design. The plant to plant and row to row distances were maintained as 25 and $75 \mathrm{~cm}$, respectively.

\subsection{Quality Parameters}

The grain and plant samples containing leaves and stem will be collected and grounded into fine powder and the following quality traits including grain protein percentage, grain oil percentage, grain starch percentage, grain crude fibre percentage, nutrient detergent fibre, acid detergent fibre, fodder cellulose, carbohydrates, fodder crude fibre, fodder crude protein and fodder moisture percentage were estimated using (Proximate analysis, AOAC (Association of Official Analytical Chemists) 1996).

The percentage of the embryo was recorded by using following formula:

Embryo \% = [Embryo weight/Seed weight $] \times 100$

The fresh weight of the sample was recorded with the help of electronic balance (OHAUS-GT4000, USA). The sample was dried out in oven at $106^{\circ} \mathrm{C}$ for 24hours. The dried sample was again weighed with the help of electronic balance. The difference in the weight was recorded that was the estimation of dry matter in the sample.

Dry matter $\%=[$ Fresh sample weight - dry sample weight] $\times 100$

The moisture percentage was calculated was using following formula.

Moisture $\%=[$ Sample amount of water $(\mathrm{FW}$ DW)/Sample weight (FW) $] \times 100$

$\mathrm{FW}=$ Fresh sample weight, $\mathrm{DW}=$ Dry sample weight

\subsection{Statistical Analysis}

The data were analyzed statistically using analysis of variance technique (Steel et al. 1997) and Duncan Multiple Range (DMR) test at $5 \%$ significance probability level and it was used to compare the treatments means. Significantly varying genotypes were subjected to North Carolina Design II matting scheme (Comstock and Robinson, 1948, 1952) to estimate their gene action. Phenotypic $\left(\mathbf{r}_{\mathbf{p}}\right)$ and genotypic $\left(\mathbf{r}_{\mathbf{g}}\right)$ correlation coefficient was calculated as outlined by Kwon and Torrie (1964).

\section{Results and Discussion}

It was suggested that significant differences were recorded for grain protein percentage. The mean performance of parents and $F_{1}$ hybrids indicated that average grain protein percentage was recorded as $9.7396 \pm 0.0712 \%$ (Table 1 ). It was also persuaded from Table 1 that higher heritability (96.70\%) and lower genetic advance (3.619\%) was recorded for grain protein percentage. It was suggested from Table 4 that higher grain protein percentage was recorded for EV-1097 $\times \mathrm{EV}$ 347 (10.77\%), EV-1097×F-96 (10.67\%), B-327×Pop/209 (10.33\%) and EV-1097×EV-340 (10.33\%) while lower grain protein percentage was recorded for Sh-139 $\times$ B-316 (9.267\%), Sh-139×E-322 (9.200\%), Sh-139 $\times$ EV-340 (9.200\%) and Raka-posh $\times$ Pop/209 (9.167\%). The higher values of grain protein percentage for $F_{1}$ hybrids $E V$ 1097×EV-347, EV-1097×F-96, B-327×Pop/209 and EV$1097 \times \mathrm{EV}-340$ indicated that selection of EV-1097, B-327, EV-347, F-96 and EV-340 may be used for developing higher grain protein percentage hybrids. It was found from Table 1 that significant differences were recorded for grain oil percentage. The mean performance of parents 
and $F_{1}$ hybrids indicated that average grain oil percentage $\quad$ was recorded as $4.85 \pm 0.0619 \%$.

Table 1. Genetic components for various grain and fodder quality traits in maize

\begin{tabular}{|c|c|c|c|c|c|c|c|c|c|c|c|c|}
\hline \\
\hline $\begin{array}{c}\text { Source } \\
\text { of } \\
\text { vartiatio } \\
n\end{array}$ & $\begin{array}{c}\text { Grain } \\
\text { protein } \\
\%\end{array}$ & $\begin{array}{l}\text { Grain } \\
\text { oil \% }\end{array}$ & $\begin{array}{c}\text { Grain } \\
\text { crude } \\
\text { fiber } \\
\%\end{array}$ & $\begin{array}{c}\text { Grain } \\
\text { starch } \\
\%\end{array}$ & $\begin{array}{c}\text { Embryo } \\
\%\end{array}$ & $\begin{array}{c}\text { Acid } \\
\text { deterge } \\
\text { nt } \\
\text { fiber \% }\end{array}$ & $\begin{array}{c}\text { Neutrie } \\
\text { nt } \\
\text { deterge } \\
\text { nt } \\
\text { fiber \% }\end{array}$ & $\begin{array}{c}\text { Fodder } \\
\text { Cellulose } \\
\%\end{array}$ & $\begin{array}{c}\text { Fodder } \\
\text { dry } \\
\text { matter } \\
\%\end{array}$ & $\begin{array}{c}\text { fodder } \\
\text { crude } \\
\text { fiber } \\
\%\end{array}$ & $\begin{array}{c}\text { Fodder } \\
\text { crude } \\
\text { protein } \\
\%\end{array}$ & $\begin{array}{c}\text { Fodder } \\
\text { moisture } \\
\%\end{array}$ \\
\hline M.S.S & $0.463 * *$ & $\begin{array}{c}0.313^{*} \\
*\end{array}$ & $\begin{array}{c}0.115^{*} \\
*\end{array}$ & $1.332 *$ & $0.165^{*}$ & $5.532 *$ & $38.761^{*}$ & $36.316^{*}$ & $2.058 *$ & $\begin{array}{c}5.500 * \\
*\end{array}$ & $4.980 *$ & $0.083^{*}$ \\
\hline G.M $M$ & $9.7396 \pm$ & $4.85 \pm$ & $\begin{array}{c}9.4392 \\
+\end{array}$ & 71.966 & $11.77 \pm$ & $22.899 \pm$ & $51.696 \pm$ & $28.797 \pm$ & $40.178 \pm$ & 26.845 & $10.353 \pm$ & $9.0951 \pm$ \\
\hline E & 0.0712 & 0.0619 & $\stackrel{ \pm}{ \pm}+0579$ & $\stackrel{ \pm}{ \pm}$ & 0.1120 & 0.2528 & 0.3078 & 0.2755 & 0.2442 & $\stackrel{ \pm}{ \pm}$ & 0.1072 & 0.0142 \\
\hline G.V & 0.510 & 0.101 & 0.035 & 0.427 & 0.043 & 1.780 & 12.826 & 11.996 & 0.627 & 1.822 & 1.649 & 0.028 \\
\hline GCV & 3.971 & 6.542 & 1.987 & 0.908 & 1.756 & 5.826 & 6.928 & 12.027 & 1.970 & 5.028 & 12.402 & 1.830 \\
\hline PV & 0.155 & 0.104 & 0.039 & 0.444 & 0.055 & 1.844 & 12.920 & 12.072 & 0.686 & 1.833 & 1.660 & 0.028 \\
\hline PCV & 4.038 & 6.665 & 2.080 & 0.926 & 1.997 & 5.930 & 6.953 & 12.065 & 2.062 & 5.044 & 12.445 & 1.837 \\
\hline $\mathrm{EV}$ & 0.005 & 0.004 & 0.003 & 0.017 & 0.013 & 0.064 & 0.095 & 0.076 & 0.060 & 0.012 & 0.011 & 0.0001 \\
\hline $\mathrm{ECV}$ & 0.731 & 1.277 & 0.614 & 0.182 & 0.951 & 1.104 & 0.595 & 0.957 & 0.608 & 0.402 & 1.035 & 0.157 \\
\hline $\mathrm{h}_{\text {bs } \%}^{2}$ & 96.70 & 96.30 & 91.30 & 96.10 & 77.30 & 96.50 & 99.30 & 99.40 & 91.30 & 99.40 & 99.30 & 99.30 \\
\hline S.E h ${ }^{2}$ & 0.299 & 0.364 & 0.607 & 0.177 & 0.524 & 0.087 & 0.033 & 0.034 & 0.144 & 0.086 & 0.091 & 0.700 \\
\hline \multicolumn{5}{|c|}{ Source of variation } & \multicolumn{2}{|c|}{$\begin{array}{c}\text { Ether extractable } \\
\text { fat } \%\end{array}$} & \multicolumn{4}{|c|}{$\begin{array}{l}\text { Fodder } \\
\text { ash } \%\end{array}$} & & \\
\hline \multicolumn{5}{|c|}{ Mean Sum of Squares (M.S.S) } & \multicolumn{2}{|c|}{$0.025^{* *}$} & \multicolumn{2}{|r|}{$10.760 *$} & \multicolumn{2}{|c|}{$1.148 * *$} & & \\
\hline \multicolumn{5}{|c|}{ Grand mean (G.M) } & \multicolumn{2}{|c|}{2.9055} & & 41.861 & \multicolumn{2}{|c|}{8.9026} & & \\
\hline \multicolumn{5}{|c|}{ Standard error (S.E) } & \multicolumn{2}{|c|}{0.0262} & & 0.3720 & \multicolumn{2}{|c|}{0.100} & & \\
\hline \multicolumn{5}{|c|}{ Genotypic variance (GV) } & \multicolumn{2}{|c|}{0.008} & & 5.183 & \multicolumn{2}{|c|}{0.559} & & \\
\hline \multicolumn{5}{|c|}{ Genotypic coefficient of variance (GCV \%) } & \multicolumn{2}{|c|}{3.049} & & 5.439 & \multicolumn{2}{|c|}{6.282} & & \\
\hline \multicolumn{5}{|c|}{ Phenotypic variance (PV) } & \multicolumn{2}{|c|}{0.009} & & 5.649 & \multicolumn{2}{|c|}{0.589} & & \\
\hline \multicolumn{5}{|c|}{ Phenotypic coefficient of variance (PCV \%) } & \multicolumn{2}{|c|}{3.179} & & 5.678 & \multicolumn{2}{|c|}{6.619} & & \\
\hline \multicolumn{5}{|c|}{ Environmental Variance (EV) } & \multicolumn{2}{|c|}{0.001} & & 0.466 & \multicolumn{2}{|c|}{0.029} & & \\
\hline Enviro & nmental coe & icient of & ariance $(\mathrm{E}$ & $\mathrm{V} \%)$ & & & & 1.113 & & & & \\
\hline & Broad sen & heritabil & $y\left(h_{\text {bs } \%}^{2}\right)$ & & & & & 91.70 & & & & \\
\hline Standard & error for bi & ad sense & ritability &.$\left.E h^{2}{ }_{b s}\right)$ & & & & 1.453 & & & & \\
\hline & Genetic & advance & A \%) & & & & & 9.143 & 14 & & & \\
\hline
\end{tabular}

It was also persuaded from Table 1 that higher heritability (96.30\%) and lower genetic advance (8.98\%) was recorded for grain oil percentage. It was indicated from Table 4 that higher grain oil percentage was recorded for B-327×B-316 (5.27\%), Raka-poshi×B-316 (5.37\%), E$336 \times$ Pop/209 (5.40\%) and Raka-poshi $\times$ EV-340 (5.33\%) while lower grain oil percentage was recorded for Sh-139 (4.13\%), E-322 (4.20\%), B-11×EV-340 (4.27\%) and F-96 $(4.03 \%)$. The higher values of grain oil percentage for $F_{1}$ hybrids B-327×B-316, Raka-poshi×B-316, E$336 \times$ Pop/209 and Raka-poshi $\times E V-340$ indicated that selection of Raka-poshi, B-327, Pop/209, B-316 and EV340 may be used for developing higher grain oil percentage hybrids. Findings were reported similar to Yousaf and Saleem, 2001. It was indicated from Table 1 that significant differences were recorded for grain crude fiber percentage. The mean performance of parents and $F_{1}$ hybrids indicated that average grain crude fiber percentage was recorded as $9.4392 \pm 0.0579 \%$. It was also persuaded from Table 1 that higher heritability (91.30\%) and lower genetic advance $(2.66 \%)$ was recorded for grain crude fiber percentage. It was suggested from Table 4 that higher grain crude fiber percentage was recorded for E$336 \times$ B-316 (9.87\%), E-336 × E-322 (9.80\%), EV-1097 (9.80\%) and E-336 $\times$ EV-340 (9.77\%) while lower grain crude fiber percentage was recorded for Sh-139 (9.13\%), B-316 (9.12\%), E-336 $\times$ EV-347 (9.10\%) and B-11 (9.10\%). The higher values of grain crude fiber percentage for $F_{1}$ hybrids E-336 $\times$ B-316, E-336 $\times$ E-322 and E$336 \times \mathrm{EV}-340$ indicated that selection of EV-1097, E-336, B-316, E-322 and EV-340 may be used for developing higher grain crude fiber percentage hybrids[4,17,18,19,20].

It was shown from Table 1 that significant differences were recorded for grain starch percentage. The mean performance of parents and $F_{1}$ hybrids indicated that average grain starch percentage was recorded as $71.966 \pm 0.1313 \%$. It was also persuaded from Table 1 that higher heritability (91.10\%) and lower genetic advance $(1.25 \%)$ was recorded for grain starch percentage. It was suggested from Table 4 that higher grain starch percentage was recorded for B-11×B-316 (74.20\%), B-11×Pop/209 (73.17\%), Sh-139 (73.63\%) and Raka-poshi (73.20\%) while lower grain starch percentage was recorded for Raka-poshi $\times$ EV-347 (71.17\%), E-336 (71.20\%), Rakaposhi $\times$ E-322 (71.20\%) and B-11×F-96 (71.17\%). The higher values of grain starch percentage for $F_{1}$ hybrids $B$ $11 \times \mathrm{B}-316$ and $\mathrm{B}-11 \times \mathrm{Pop} / 209$ indicated that selection of B-11, B-316, Raka-poshi and Sh-139 may be used for developing higher grain starch percentage hybrids. Findings were reported similar to $[6,18,20]$.

It was found from Table 1 that significant differences were recorded for grain embryo percentage. The mean performance of parents and $\mathrm{F}_{1}$ hybrids indicated that average grain embryo percentage was recorded as $11.77 \pm 0.1120 \%$. It was also indicated from Table 1 that higher heritability (77.30\%) and lower genetic advance (2.16\%) was recorded for grain embryo percentage. It was suggested from Table 4 that higher grain embryo percentage was recorded for B-11×EV-347 (12.60\%), E$336 \times \mathrm{Pop} / 209$ (12.20\%), E-336 (12.13\%) and EV-1097 (12.20\%) while lower grain embryo percentage was recorded for Raka-poshi $\times$ F-96 (11.50\%), Sh-139×EV-347 (11.20\%), Raka-poshi×E-322 (11.57\%) and Sh-139×F-96 (11.37\%). The higher values of grain embryo percentage for $F_{1}$ hybrids B-11 $\times E V-347$ and E-336 $\times$ Pop/209 indicated that selection of B-11, E-336, EV-347 and EV1097 may be used for developing higher grain embryo percentage hybrids with greater hybrid vigor. Greater embryo percentage indicated the health of the seed and seedlings. Similar results were reported by 
$[4,11,17,18,19,21]$. It was indicated from Table 1 that significant differences were recorded for fodder acid detergent fiber percentage.

The mean performance of parents and $F_{1}$ hybrids indicated that average fodder acid detergent fiber percentage was recorded as $22.899 \pm 0.2528 \%$. It was also persuaded from Table 1 that higher heritability (96.50\%) and lower genetic advance (8.01\%) was recorded for fodder acid detergent fiber percentage. It was suggested from Table 4a that higher fodder acid detergent fiber percentage was recorded for E-336 $\times \mathrm{EV}-347$ (26.10\%), B$11 \times$ EV-340 (25.03\%), B-11 (25.03\%) and E-336 (24.87\%) while lower fodder acid detergent fiber percentage was recorded for Raka-poshi×F-96 (19.97\%), E-336 (20.80\%), Raka-poshi×Pop/209 (20.37\%) and B-327×F-96 (20.63\%). The higher values of fodder acid detergent fiber percentage for $\mathrm{F}_{1}$ hybrids E-336 $\times \mathrm{EV}-347$ and $\mathrm{B}-11 \times \mathrm{EV}-$ 340 indicated that selection of E-336, B-11, EV-347 and EV-340 may be used for developing good quality fodder acid detergent fiber percentage hybrids. Higher fodder acid detergent fiber indicated better quality of maize fodder [1,4,11,18,21,22].

It was suggested from Table 1 that significant differences were recorded for fodder nutrient detergent fiber percentage. The mean performance of parents and $F_{1}$ hybrids indicated that average fodder nutrient detergent fiber percentage was recorded as $51.696 \pm 0.3078 \%$. It was also persuaded from Table 1 that higher heritability (99.30\%) and lower genetic advance (9.66\%) was recorded for fodder nutrient detergent fiber percentage. It was indicated from Table 4a that higher fodder nutrient detergent fiber percentage was recorded for EV1097×EV-340 (56.83\%), EV-1097×E-322 (58.87\%), EV$1097 \times$ F-96 (57.97\%), Sh-139 $\times$ EV-340 (55.76\%) and B$327 \times$ EV-340 (55.67\%) while lower fodder nutrient detergent fiber percentage was recorded for B-327×E-322 (40.10\%), B-327×F-96 (43.60\%), Raka-poshi $\times$ Pop/209 (45.03\%) and B-327×EV-347 (45.40\%). The lower values of fodder nutrient detergent fiber percentage for $F_{1}$ hybrids B-327×E-322, B-327×F-96, Raka-poshi $\times$ Pop/209 and B$327 \times \mathrm{EV}-347$ indicated that selection of B-327, E-322, EV-347, Raka-poshi and F-96 may be used for developing good quality fodder nutrient detergent fiber percentage hybrids. Lower fodder nutrient detergent fiber percentage indicated better quality of maize fodder [23-27].

It was shown from Table 1 that significant differences were recorded for fodder cellulose percentage. The mean performance of parents and $\mathrm{F}_{1}$ hybrids indicated that average fodder cellulose percentage was recorded as $28.797 \pm 0.2755 \%$. It was also persuaded from Table 1 that higher heritability (99.40\%) and moderate genetic advance (16.79\%) was recorded for fodder cellulose percentage. It was suggested from Table 4a that higher fodder cellulose percentage was recorded for EV-1097 $\times \mathrm{EV}-340$ (33.97\%), EV-1097×E-322 (36.43\%), EV-1097×F-96 (34.33\%) and B-327×EV-340 (33.53\%) while lower fodder cellulose percentage was recorded for B-327 $\times$ E-322 (17.20\%), B$327 \times$ F-96 (22.97\%), EV-1097 (24.47\%) and B-327×EV347 (24.40\%). The lower values of fodder cellulose percentage for $\mathrm{F}_{1}$ hybrids $\mathrm{B}-327 \times \mathrm{E}-322, \mathrm{~B}-327 \times \mathrm{F}-96$ and B-327 $\times \mathrm{EV}-347$ indicated that selection of B-327, E-322, EV-347, EV-1097 and F-96 may be used for developing good quality fodder cellulose percentage hybrids. Lower fodder cellulose percentage indicated better quality of maize fodder [26,28,29].

It was indicated from Table 1 that significant differences were recorded for fodder dry matter percentage. The mean performance of parents and $F_{1}$ hybrids indicated that average fodder dry matter percentage was recorded as $40.178 \pm 0.2442 \%$. It was also persuaded from Table 1 that higher heritability (91.30\%) and lower genetic advance (2.64\%) was recorded for fodder dry matter percentage. It was suggested from Table 4a that higher fodder dry matter percentage was recorded for $\mathrm{EV}-1097 \times \mathrm{Pop} / 209 \quad$ (41.67\%), $\mathrm{EV}-1097 \times \mathrm{EV}-347$ (41.33\%), EV-1097×E-322 (41.40\%), E-336×F-96 (41.57\%) and Sh-139×Pop/209 (41.40\%) while lower fodder dry matter percentage was recorded for Rakaposhi $\times$ B-316 (39.10\%), EV-340 (38.93\%), EV-347 (38.13\%) and E-322 (38.03\%). The higher values of fodder dry matter percentage for $F_{1}$ hybrids EV1097×Pop/209, EV-1097×EV-347, EV-1097×E-322, E$336 \times$ F-96 and Sh-139 $\times$ Pop/209 indicated that selection of E-336, E-322, Sh-139, EV-1097 and F-96 may be used for developing good quality fodder dry matter percentage hybrids.

Higher fodder dry matter percentage indicated better quality of maize fodder. Findings were reported similar to $[30,31,32]$. It was found from Table 1 that significant differences were recorded for fodder crude fiber percentage. The mean performance of parents and $F_{1}$ hybrids indicated that average fodder crude fiber percentage was recorded as $26.845 \pm 0.1080 \%$. It was also persuaded from Table 1 that higher heritability (99.40\%) and lower genetic advance (7.02\%) was recorded for fodder crude fiber percentage. It was suggested from Table 4a that higher fodder crude fiber percentage was recorded for EV-1097 (28.50\%), B-327 (29.31\%), Rakaposhi (28.99\%), EV-1097×F-96 (28.40\%) and Sh$139 \times$ EV-347 (28.50\%) while lower fodder crude fiber percentage was recorded for E-336 $\times$ EV-340 (24.30\%), B-11 (24.31\%) and E-336 (24.10\%). The higher values of fodder crude fiber percentage for $F_{1}$ hybrids EV-1097 $\times$ F96 and Sh-139 $\times$ EV-347 indicated that selection of B-327, EV-347, Raka-poshi, Sh-139, EV-1097 and F-96 may be used for developing good quality fodder crude fiber percentage hybrids. Higher fodder crude fiber percentage indicated better quality of maize fodder [29,33,34].

It was suggested from Table 1 that significant differences were recorded for fodder crude protein percentage. The mean performance of parents and $F_{1}$ hybrids indicated that average fodder crude protein percentage was recorded as $10.353 \pm 0.1072 \%$. It was also persuaded from Table $1 \mathrm{~b}$ that higher heritability (99.30\%) and moderate genetic advance $(17.30 \%)$ was recorded for fodder crude protein percentage. It was suggested from Table $4 \mathrm{~b}$ that higher fodder crude protein percentage was recorded for Sh-139 (12.69\%), Raka-poshi (13.20\%), E$336 \times \mathrm{Pop} / 209$ (12.69\%), B-11×B-316 (11.81\%) and E$336 \times$ E-322 (11.96\%) while lower fodder crude protein percentage was recorded for B-11×Pop/209 (8.82\%), B$327 \times$ EV-340 (8.53\%), B-327×F-96 (7.81\%) and EV$1097 \times \mathrm{EV}-347$ (7.73\%). The higher values of fodder crude protein percentage for $\mathrm{F}_{1}$ hybrids $\mathrm{E}-336 \times \mathrm{Pop} / 209$, B$11 \times \mathrm{B}-316$, and E-336 $\times \mathrm{E}-322$ indicated that selection of $\mathrm{E}-$ 336, Raka-poshi, Sh-139, EV-1097 and Pop/209 may be used for developing good quality fodder crude protein 
percentage hybrids. Higher fodder crude protein percentage indicated better quality of maize fodder [20]. It was found from Table 1 that significant differences were recorded for fodder moisture percentage.

The mean performance of parents and $F_{1}$ hybrids indicated that average fodder moisture percentage was recorded as $9.0951 \pm 0.0142 \%$. It was also persuaded from Table 1 that higher heritability (99.30\%) and lower genetic advance $(2.55 \%)$ was recorded for fodder moisture percentage. It was suggested from Table $4 \mathrm{~b}$ that higher fodder moisture percentage was recorded for B-327 (9.24\%), E-336 (9.24\%), E-336 × E-322 (9.22\%), E$336 \times$ F-96 (9.24\%) and B-327×EV-340 (9.21\%) while lower fodder moisture percentage was recorded for B$11 \times$ Pop/209 (8.79\%), B-11×B-316 (8.92\%), B-316 (8.15\%) and EV-1097×Pop/209 (8.91\%). The higher values of fodder moisture percentage for $F_{1}$ hybrids $E$ $336 \times \mathrm{E}-322, \mathrm{E}-336 \times \mathrm{F}-96$ and $\mathrm{B}-327 \times \mathrm{EV}-340$ indicated that selection of E-336 and B-327 may be used for developing good quality fodder moisture percentage hybrids. Higher fodder moisture percentage indicated better quality of maize fodder (Khalil et al., 2000; Awan et al. 2001; Yousaf and Saleem. 2001; Mazur et al. 2001; Dubey et al., 2001; Rai et al. 2004 and Xiang et al. 2010).

It was revealed from Table 1 that significant differences were recorded for fodder ether extractable fat percentage. The mean performance of parents and $F_{1}$ hybrids indicated that average fodder ether extractable fat percentage was recorded as $2.9055 \pm 0.0262 \%$. It was also persuaded from Table 1 that higher heritability (92.00\%) and lower genetic advance $(9.09 \%)$ was recorded for fodder ether extractable fat percentage. It was suggested from Table $4 \mathrm{~b}$ that higher fodder ether extractable fat percentage was recorded for F-96 (3.103\%), B-327×EV-347 (3.027\%), B$327 \times$ F-96 (3.017\%) and Sh-139×B-316 (3.007\%) while lower fodder ether extractable fat percentage was recorded for B-11×F-96 (2.727\%), Raka-poshi (2.753\%), B-327 (2.710\%) and EV-1097 (2.747\%). The higher values of fodder ether extractable fat percentage for $F_{1}$ hybrids $B-$ $327 \times$ EV-347, B-327 $\times$ F-96 and Sh-139 $\times$ B-316 indicated that selection of E-336, F-96, B-316 and B-327 may be used for developing good quality fodder ether extractable fat percentage hybrids. Higher fodder ether extractable fat percentage indicated better quality of maize fodder. Findings were found similar to $[11,25]$.

It was shown from Table 1 that significant differences were recorded for fodder nitrogen free extract percentage. The mean performance of parents and $F_{1}$ hybrids indicated that average fodder nitrogen free extract percentage was recorded as $41.861 \pm 0.3720 \%$. It was also persuaded from Table 1 that higher heritability (91.75\%) and lower genetic advance (9.143\%) was recorded for fodder nitrogen free extract percentage. It was suggested from Table 4b that higher fodder ether extractable fat percentage was recorded for E-336 (46.11\%), B$11 \times$ Pop/209 (46.28\%), B-327×F-96 (46.28\%) and E$336 \times$ E-322 (46.18\%) while lower fodder nitrogen free extract percentage was recorded for B-327 $\times$ Pop/209 (39.11\%), Raka-poshi (37.84\%), EV-347 (39.56\%) and Sh-139 (38.84\%). The higher values of fodder nitrogen free extract percentage for $\mathrm{F}_{1}$ hybrids B- $11 \times \mathrm{Pop} / 209$, B$327 \times \mathrm{F}-96$ and E-336 $\times$ E-322 indicated that selection of E336, F-96, B-11 and B-327 may be used for developing good quality fodder nitrogen free extract percentage hybrids. Higher fodder nitrogen free extract percentage indicated better quality of maize fodder [20,24,25].

It was indicated from Table 1 that significant differences were recorded for fodder ash percentage. The mean performance of parents and $\mathrm{F}_{1}$ hybrids indicated that average fodder ash percentage was recorded as $8.9026 \pm 0.100 \%$. It was also persuaded from Table 1 that higher heritability (94.91\%) and moderate genetic advance (14.362\%) was recorded for fodder ash percentage. It was suggested from Table $4 \mathrm{~b}$ that higher fodder ash percentage was recorded for EV-1097×F-96 (9.69\%), EV-1097×E322 (9.80\%), B-11×EV-340 (9.91\%) and B-11×E-322 (11.17\%) while lower fodder ash percentage was recorded for B-11 × F-96 (8.14\%), Raka-poshi (8.06\%), B-11×EV347 (8.05\%) and Sh-139 (8.11\%). The higher values of fodder ash percentage for $F_{1}$ hybrids EV-1097×F-96, EV$1097 \times \mathrm{E}-322, \mathrm{~B}-11 \times \mathrm{EV}-340$ and $\mathrm{B}-11 \times \mathrm{E}-322$ indicated that selection of EV-1097, F-96, B-11 and EV-340 may be used for developing good quality fodder ash percentage hybrids. Higher fodder ash percentage indicated better quality of maize fodder [20,35].

\subsection{Correlation Analysis}

It was found that a positive significant genotypic and phenotypic correlation was found between grain protein percentage and grain oil percentage, embryo percentage, nutrient detergent fiber, cellulose percentage and dry matter percentage while a significant and negative correlation was found for fodder crude protein and ether extractable fat percentage at both genotypic and phenotypic levels (Table 2 and 2a). Significant correlations indicated that selection of good grain and fodder quality may be helpful for improving maize germplasm (Xiang et al. 2010; Ali et al. 2011b and Ali et al. 2012a). It was suggested that a positive significant genotypic and phenotypic correlation was found between grain oil percentage and grain protein percentage, embryo percentage and nitrogen free extract percentage while a significant and negative correlation was found for grain starch percentage, fodder crude protein and ether extractable fat percentage at both genotypic and phenotypic levels. Significant correlations indicated that selection of good grain and fodder quality may be helpful for improving maize breeding material (Table 2 and 2a). Findings were found similar to Ali et al [7].

It was revealed from Table 2 and 2a that a positive significant genotypic and phenotypic correlation was found between grain crude fiber percentage and embryo percentage and fodder moisture percentage. It was suggested that a negative significant genotypic and phenotypic correlation was found between grain starch percentage and grain oil percentage, nutrient detergent fiber, cellulose percentage, fodder moisture percentage and nitrogen free extract percentage (Table 2 and 2a). The quality of fodder may be enhanced by selecting genotypes on the basis of nutrient detergent fiber percentage [15,36]. It was persuaded from Table 2 and 2 a that a positive significant genotypic and phenotypic correlation was found between embryo percentage and grain oil and protein percentage, grain crude fiber percentage, acid detergent fiber and fodder moisture percentage while a significant and negative correlation was found for nutrient detergent fiber, cellulose percentage, fodder ash 
percentage and ether extractable fat percentage at both genotypic and phenotypic levels.

Table 2. Genotypic correlations of various grain and fodder quality traits in maize

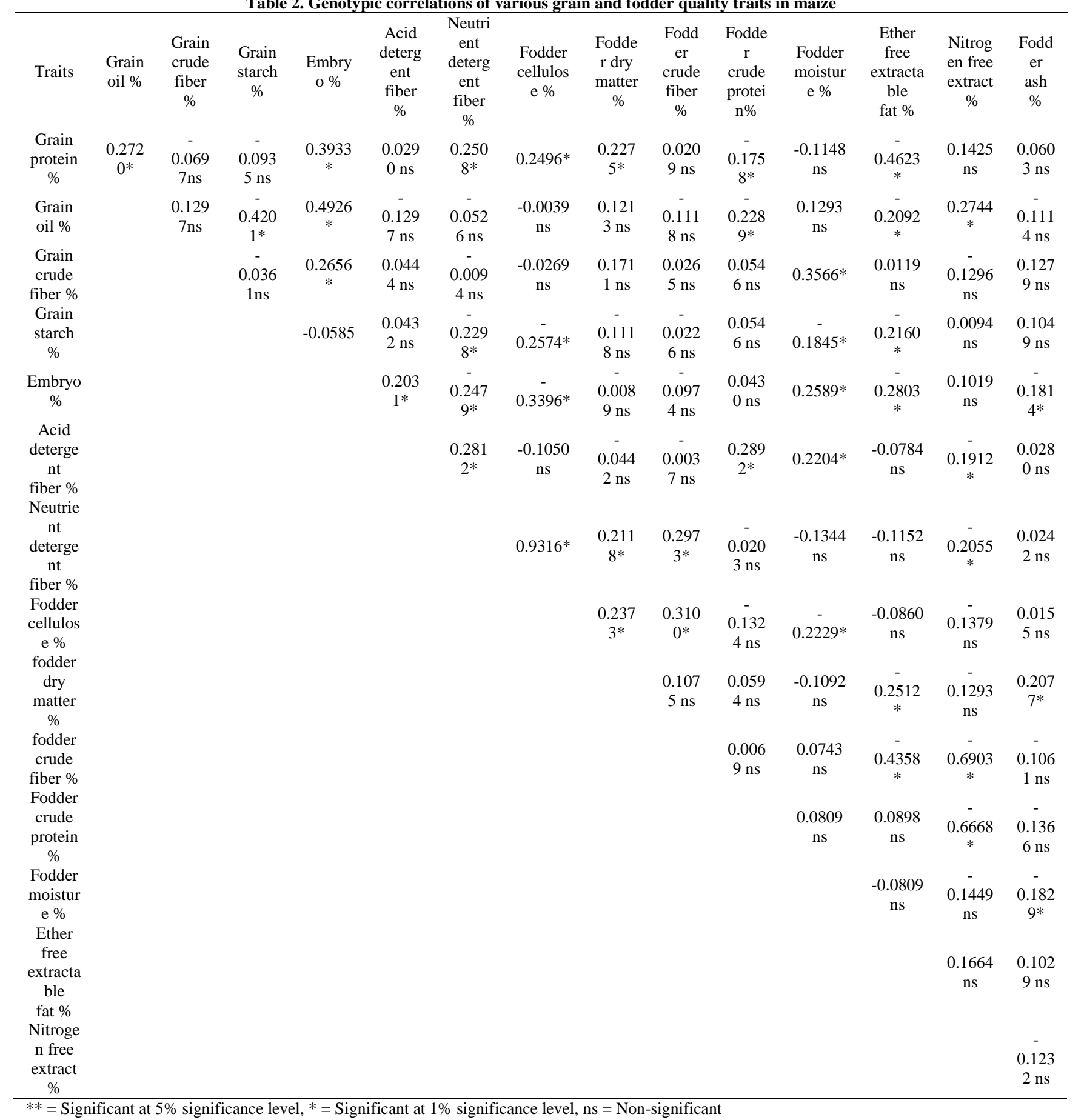

It was found that a positive significant genotypic and (Table 2 and 2a). Positive and significant correlations phenotypic correlation was found between acid detergent fiber and embryo percentage, nutrient detergent fiber, fodder crude protein percentage and fodder moisture percentage while a significant and negative correlation was found for nitrogen free extract percentage at both genotypic and phenotypic levels (Table 2 and 2a). It was revealed that a positive significant genotypic and phenotypic correlation was found between nutrient detergent fiber and grain protein percentage, acid detergent fiber, fodder crude fiber percentage, cellulose percentage and fodder dry matter percentage while a significant and negative correlation was found for embryo percentage, grain starch percentage and nitrogen free extract percentage at both genotypic and phenotypic levels suggested that grain and fodder quality may be improved by selecting genotypes on the basis of grain protein and starch maize germplasm $[37,38]$. It was suggested that a positive significant genotypic and phenotypic correlation was found between cellulose percentage and nutrient detergent fiber, grain protein percentage, fodder crude fiber percentage and fodder dry matter percentage while a significant and negative correlation was found for embryo percentage, grain starch percentage and fodder moisture percentage at both genotypic and phenotypic levels (Table 2 and 2a). It was revealed that a positive significant genotypic and phenotypic correlation was found between fodder dry matter percentage and cellulose percentage, nutrient detergent fiber, grain protein percentage and 
fodder ash percentage while a significant and negative correlation was found for nitrogen free extract percentage at both genotypic and phenotypic levels (Table 2 and 2a). Good grain and fodder quality may be improved for maize germplasm [7,15,31,38]. It was suggested from Table 2 and $2 \mathrm{a}$ that a positive significant genotypic and phenotypic correlation was found between fodder crude fiber percentage and cellulose percentage and nutrient detergent fiber while a significant and negative correlation was found for ether extractable fat percentage and nitrogen free extract percentage at both genotypic and phenotypic levels.

Table 2a. Phenotypic correlations among various grain and fodder quality traits in maize

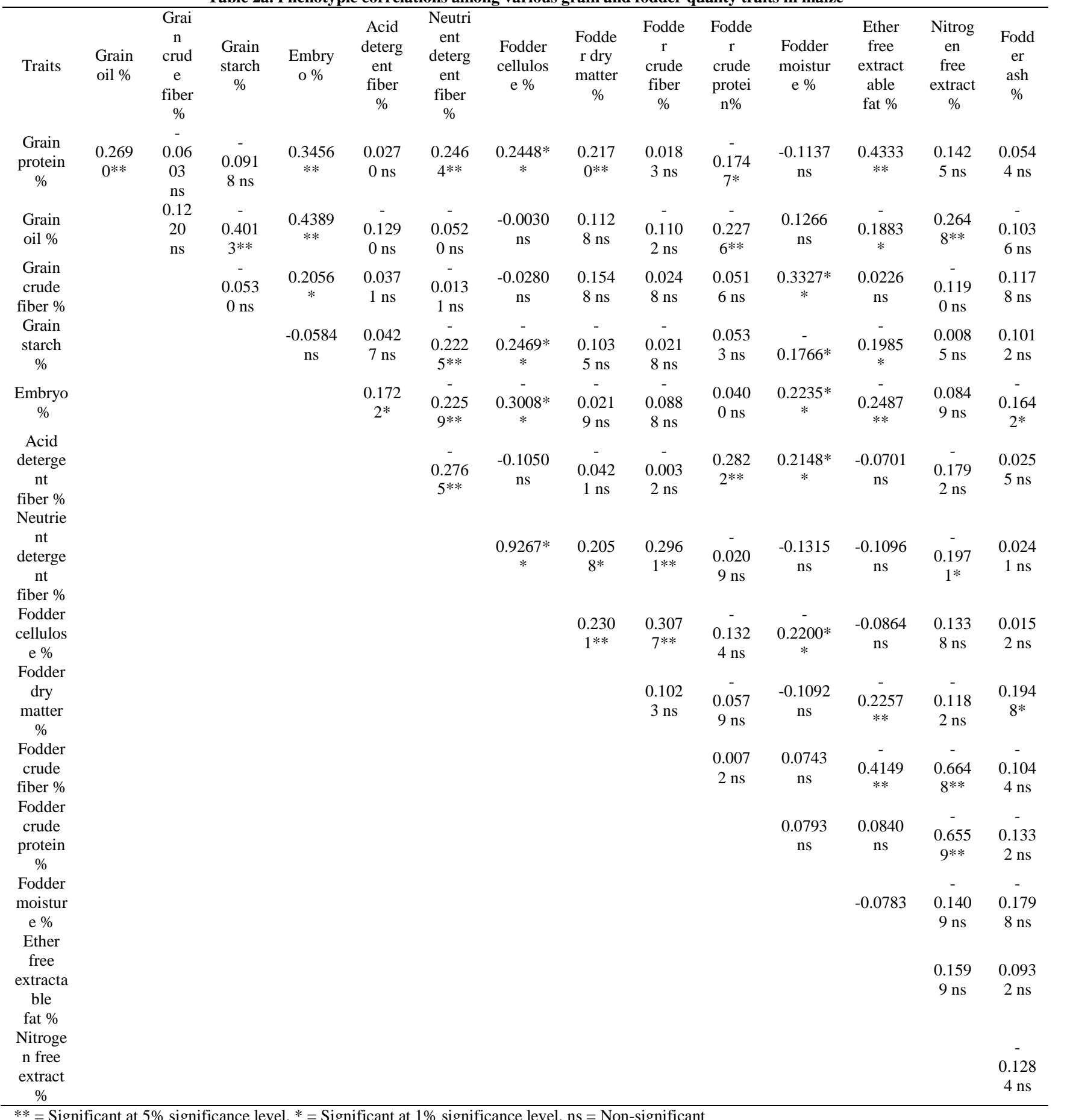

It was shown from results that a positive significant genotypic and phenotypic correlation was found between fodder crude protein percentage and acid detergent fiber while a significant and negative correlation was found for grain protein and oil percentage and nitrogen free extract percentage at both genotypic and phenotypic levels (Table 2 and 2a). It was indicated from results that a positive significant genotypic and phenotypic correlation was found between fodder moisture percentage and grain crude fiber percentage, embryo percentage and acid detergent fiber while a significant and negative correlation was found for grain starch percentage, cellulose percentage and fodder ash percentage at both genotypic and phenotypic levels (Table 2 and 2a). Significant correlations higher grain and fodder quality maize germplasm may be developed [18,24,28,38,39].

It was persuaded from Table 2 and 2a that a negative significant genotypic and phenotypic correlation was found between fodder ether extractable fat percentage and fodder moisture percentage and grain protein, oil, starch, 
embryo percentage, fodder dry matter percentage and fodder crude fithat a positive significant genotypic and phenotypic correber percentage. It was suggested from Table 2 and 2a lation was found between fodder nitrogen free extract percentage and grain oil percentage while a significant and negative correlation was found for acid detergent fiber, nutrient detergent fiber, fodder crude fiber percentage and fodder crude protein percentage at both

genotypic and phenotypic levels. It was suggested from Table 2 and 2a that a positive significant genotypic and phenotypic correlation was found between fodder ash percentage and fodder dry matter percentage while a significant and negative correlation was found for embryo percentage and fodder moisture percentage [3,7,15,21,36].

\subsection{North Carolina Mating Design-II}

Table 3(a). Analysis of variance for grain and fodder quality traits in maize (North Carolina matting design-II)

\begin{tabular}{|c|c|c|c|c|c|c|c|c|}
\hline SOV/Traits & $\begin{array}{c}\text { Grain } \\
\text { protein \% }\end{array}$ & $\begin{array}{l}\text { Grain } \\
\text { oil \% }\end{array}$ & $\begin{array}{l}\text { Grain crude } \\
\text { fiber } \%\end{array}$ & $\begin{array}{c}\text { Grain } \\
\text { starch \% }\end{array}$ & Embryo \% & $\begin{array}{l}\text { Acid detergent } \\
\text { fiber } \%\end{array}$ & $\begin{array}{c}\text { Neutrient } \\
\text { detergent fiber \% }\end{array}$ & $\begin{array}{c}\text { Fodder } \\
\text { cellulose \% }\end{array}$ \\
\hline Replication & $0.0056 \mathrm{~ns}$ & $0.0403 \mathrm{~ns}$ & $0.0192 \mathrm{~ns}$ & $0.0604 \mathrm{~ns}$ & $0.0278 \mathrm{~ns}$ & $0.2973 \mathrm{~ns}$ & $0.111 \mathrm{~ns}$ & $0.022 \mathrm{~ns}$ \\
\hline Males & $0.1714^{* *}$ & $0.1474^{* *}$ & $0.1340^{*}$ & $1.1781^{*}$ & $0.1363^{* *}$ & 4.1819* & $35.281 *$ & $18.827 *$ \\
\hline Females & $2.1185^{*}$ & $0.4896 *$ & $0.1185^{*}$ & $3.0277^{*}$ & $0.3305^{*}$ & 18.3353* & $162.591^{*}$ & 158.548* \\
\hline $\mathrm{M} \times \mathrm{F}$ & $0.2161 *$ & $0.2011^{*}$ & 0.0993* & $0.9400^{* *}$ & $0.1536^{* *}$ & $3.2882 *$ & $25.672 *$ & $22.520 * *$ \\
\hline Error & 0.01317 & 0.0101 & 0.0095 & 0.0482 & 0.0433 & 0.2369 & 0.239 & 0.255 \\
\hline
\end{tabular}

(b). various genetic components for grain and fodder quality traits in maize (North Carolina matting design-II)

\begin{tabular}{|c|c|c|c|c|c|c|c|c|}
\hline SOV/Traits & $\begin{array}{c}\text { Grain } \\
\text { protein \% }\end{array}$ & $\begin{array}{l}\text { Grain } \\
\text { oil \% }\end{array}$ & $\begin{array}{l}\text { Grain crude } \\
\text { fiber } \%\end{array}$ & $\begin{array}{c}\text { Grain } \\
\text { starch \% }\end{array}$ & Embryo \% & $\begin{array}{l}\text { Acid detergent } \\
\text { fiber } \%\end{array}$ & $\begin{array}{c}\text { Neutrient detergent } \\
\text { fiber } \%\end{array}$ & $\begin{array}{c}\text { Fodder } \\
\text { cellulose \% }\end{array}$ \\
\hline$\sigma_{m}^{2}$ & -0.002 & -0.003 & 0.002 & 0.013 & -0.001 & 0.049 & 0.534 & -0.205 \\
\hline$\sigma_{\mathrm{f}}^{2}$ & 0.106 & 0.016 & 0.001 & 0.116 & 0.009 & 0.836 & 7.607 & 7.557 \\
\hline$\sigma_{m \times f}^{2}$ & 0.068 & 0.064 & 0.029 & 0.297 & 0.037 & 1.017 & 8.478 & 7.422 \\
\hline$\sigma_{D}^{2}$ & 0.138 & 0.017 & 0.004 & 0.172 & 0.012 & 1.181 & 10.854 & 9.803 \\
\hline$\sigma_{H}^{2}$ & 0.271 & 0.255 & 0.119 & 1.189 & 0.147 & 4.068 & 33.911 & 29.688 \\
\hline$\left[\sigma_{H}^{2} / \sigma_{D}^{2}\right]^{1 / 2}$ & 1.403 & 3.827 & 5.479 & 2.627 & 3.350 & 1.856 & 1.768 & 1.740 \\
\hline
\end{tabular}

$*=$ Significant at $1 \%$ significance level, $* *=$ Significant at $5 \%$ significance level, $\mathrm{ns}=$ Non-significant $\sigma_{\mathrm{m}}^{2}=$ male additive variance, $\sigma_{\mathrm{f}}^{2}=$ Female additive variance, $\sigma_{\mathrm{m} \times \mathrm{f}}^{2}=\mathrm{m} \times \mathrm{f}$ interaction additive variance, $\sigma_{\mathrm{H}}^{2}=$ Dominance variance, $\sigma_{\mathrm{D}}^{2}=$ cumulative additive variance, $\left[\sigma^{2}{ }_{\mathrm{H}} / \sigma_{\mathrm{D}}^{2}\right]^{1 / 2}=$ Degree of dominance

Table 3a. (a). Analysis of variance for fodder quality traits of maize (North Carolina matting design-II)

\begin{tabular}{|c|c|c|c|c|c|c|c|}
\hline SOV/Traits & $\begin{array}{l}\text { Fodder dry } \\
\text { matter \% }\end{array}$ & $\begin{array}{l}\text { Fodder crude } \\
\text { fiber } \%\end{array}$ & $\begin{array}{l}\text { Fodder crude } \\
\text { protein } \%\end{array}$ & $\begin{array}{c}\text { Fodder } \\
\text { moisture \% }\end{array}$ & $\begin{array}{c}\text { Fodder ether } \\
\text { extractable fat \% }\end{array}$ & $\begin{array}{l}\text { Fodder nitrogen free extract } \\
\text { (Carbohydrate \%) }\end{array}$ & $\begin{array}{l}\text { Fodder ash } \\
\quad(\%)\end{array}$ \\
\hline Replication & $0.4504 \mathrm{~ns}$ & $0.0306 \mathrm{~ns}$ & $0.0263 \mathrm{~ns}$ & $0.0002 \mathrm{~ns}$ & $0.0016 \mathrm{~ns}$ & $0.5738 \mathrm{~ns}$ & $0.0370 \mathrm{~ns}$ \\
\hline Males & $0.8319 *$ & $1.8399 *$ & $2.0761^{* *}$ & $0.0501 * *$ & $0.0041^{* *}$ & $4.1020^{*}$ & $1.5453^{*}$ \\
\hline Females & $4.6045^{*}$ & $16.4070 *$ & $9.2478^{*}$ & $0.0572 * *$ & $0.0521^{*}$ & $12.4019 *$ & $1.7604^{*}$ \\
\hline $\mathrm{M} \times \mathrm{F}$ & $1.0589 * *$ & $2.4384^{*}$ & $4.2583^{*}$ & $0.0195 * *$ & $0.0181^{*}$ & $9.4472 *$ & $1.2101^{*}$ \\
\hline Error & 0.0797 & 0.0403 & 0.0304 & 0.0002 & 0.0020 & 0.5298 & 0.0381 \\
\hline
\end{tabular}

(b). various genetic components for fodder quality traits of maize (North Carolina matting design-II)

\begin{tabular}{|c|c|c|c|c|c|c|c|}
\hline SOV/Traits & $\begin{array}{l}\text { Fodder dry } \\
\text { matter \% }\end{array}$ & $\begin{array}{l}\text { Fodder } \\
\text { crude } \\
\text { fiber \% }\end{array}$ & $\begin{array}{l}\text { Fodder crude } \\
\text { protein } \%\end{array}$ & $\begin{array}{c}\text { Fodder } \\
\text { moisture \% }\end{array}$ & $\begin{array}{c}\text { Fodder ether } \\
\text { extractable fat \% }\end{array}$ & $\begin{array}{l}\text { Fodder nitrogen free extract } \\
\text { (Carbohydrate \%) }\end{array}$ & $\begin{array}{l}\text { Fodder } \\
\text { ash (\%) }\end{array}$ \\
\hline$\sigma_{\mathrm{m}}^{2}$ & -0.013 & -0.033 & -0.121 & 0.002 & -0.001 & -0.297 & 0.019 \\
\hline$\sigma_{f}^{2}$ & 0.197 & 0.776 & 0.277 & 0.002 & 0.002 & 0.164 & 0.031 \\
\hline$\sigma_{m \times f}^{2}$ & 0.326 & 0.799 & 1.409 & 0.006 & 0.005 & 2.973 & 0.391 \\
\hline$\sigma_{D}^{2}$ & 0.246 & 0.990 & 0.208 & 0.005 & 0.001 & -0.177 & 0.066 \\
\hline$\sigma_{H}^{2}$ & 1.306 & 3.197 & 5.637 & 0.026 & 0.021 & 11.889 & 1.563 \\
\hline$\left[\sigma_{H}^{2} / \sigma_{D}^{2}\right]^{1 / 2}$ & 2.305 & 1.797 & 5.206 & 2.251 & 3.786 & -8.194 & 4.881 \\
\hline
\end{tabular}

$*=$ Significant at $1 \%$ significance level, $* *=$ Significant at $5 \%$ significance level ns $=$ Non-significant, $\sigma_{\mathrm{m}}^{2}=$ male additive variance, $\sigma_{\mathrm{f}}^{2}=$ Female additive variance, $\sigma_{\mathrm{m} \times \mathrm{f}}^{2}=\mathrm{m} \times \mathrm{f}$ interaction additive variance, $\sigma_{\mathrm{H}}^{2}=$ Dominance variance, $\sigma_{\mathrm{D}}^{2}=$ cumulative additive variance, $\left[\sigma^{2}{ }_{\mathrm{H}} / \sigma_{\mathrm{D}}^{2}\right]^{1 / 2}=\mathrm{Degree}$ of dominance 
Table 4.Statistical significance of parents and $F_{1}$ hybrids of maize for various grain quality traits

\begin{tabular}{|c|c|c|c|c|c|}
\hline Genotypes & Grain protein \% & Grain oil \% & Grain crude fiber \% & Grain starch \% & Embryo \% \\
\hline Pop/209 & $10.20 \mathrm{BC}$ & 5.200ABCD & 9.490DEFGHI & 71.53JKLMNO & 11.77CDEFGH \\
\hline B-316 & 10.07 CD & $4.800 \mathrm{FGH}$ & $9.120 \mathrm{NO}$ & 71.77HIJKL & 11.60 FGHI \\
\hline EV-340 & $9.800 \mathrm{EFG}$ & 4.770FGHI & 9.350HIJKLM & 72.27 DEF & 11.60 FGHI \\
\hline E-322 & 9.400LMNOPQ & $4.200 \mathrm{MN}$ & 9.430 FGHIJ & $72.33 \mathrm{DE}$ & $11.57 \mathrm{GHI}$ \\
\hline F-96 & 9.433KLMNOP & $4.030 \mathrm{~N}$ & 9.520DEFGH & 72.17DEFGH & 11.60 FGHI \\
\hline EV-347 & 9.433KLMNOP & 4.730FGHIJ & 9.310IJKLMN & 71.50JKLMNO & 11.67DEFGHI \\
\hline B-11 & $10.27 \mathrm{BC}$ & $5.070 \mathrm{DE}$ & $9.100 \mathrm{O}$ & 71.50JKLMNO & 12.03 BCD \\
\hline E-336 & $10.30 \mathrm{BC}$ & 5.230ABCD & 9.270 JKLMNO & $71.20 \mathrm{O}$ & $12.13 \mathrm{BC}$ \\
\hline EV-1097Q & 9.367MNOPQ & $5.100 \mathrm{D}$ & $9.800 \mathrm{AB}$ & 72.20DEFGH & $12.20 \mathrm{~B}$ \\
\hline B-327 & 9.333MNOPQ & 4.730FGHIJ & $9.600 \mathrm{CDEF}$ & 72.20DEFGH & 11.80CDEFGH \\
\hline Raka-poshi & 9.400LMNOPQ & $4.570 \mathrm{IJK}$ & 9.330HIJKLM & $73.20 \mathrm{C}$ & 11.77CDEFGH \\
\hline Sh-139 & 9.633FGHIJKL & $4.130 \mathrm{MN}$ & $9.130 \mathrm{NO}$ & 73.63 B & 11.67DEFGHI \\
\hline B-11×Pop/209 & 9.633FGHIJKL & 4.830 FGH & 9.230 KLMNO & $73.17 \mathrm{C}$ & $11.57 \mathrm{GHI}$ \\
\hline B-11×B-316 & 9.633FGHIJKL & 4.730FGHIJ & 9.400FGHIJK & $74.20 \mathrm{~A}$ & 11.67DEFGHI \\
\hline B-11×EV-340 & $9.800 \mathrm{EFG}$ & 4.270 LM & 9.500 DEFGHI & $73.17 \mathrm{C}$ & 11.77CDEFGH \\
\hline B-11×E-322 & 9.300 NOPQ & $5.130 \mathrm{CD}$ & $9.670 \mathrm{BCD}$ & 72.23 DEFG & 11.63 EFGHI \\
\hline B-11×F-96 & $10.07 \mathrm{CD}$ & $5.130 \mathrm{CD}$ & 9.470 EFGHI & $71.17 \mathrm{O}$ & 11.67DEFGHI \\
\hline B-11×EV-347 & $10.13 \mathrm{BC}$ & $5.230 \mathrm{ABCD}$ & 9.370 GHIJKL & $71.23 \mathrm{NO}$ & $12.60 \mathrm{~A}$ \\
\hline E-336×Pop/209 & 10.10 BCD & $5.400 \mathrm{~A}$ & $9.670 \mathrm{BCD}$ & 71.37 LMNO & $12.20 \mathrm{~B}$ \\
\hline E-336×B-316 & $9.900 \mathrm{DE}$ & $5.100 \mathrm{D}$ & $9.870 \mathrm{~A}$ & 71.43KLMNO & 12.03 BCD \\
\hline E-336×EV-340 & 9.700EFGHIJ & 4.830FGH & $9.770 \mathrm{ABC}$ & 71.67JKLMN & 11.67DEFGHI \\
\hline E-336×E-322 & 9.467JKLMNO & $4.900 \mathrm{EF}$ & $9.800 \mathrm{AB}$ & 71.43KLMNO & 11.60 FGHI \\
\hline E-336×F-96 & 9.567GHIJKLM & 4.770FGHI & 9.370GHIJKL & $71.30 \mathrm{MNO}$ & 11.70DEFGHI \\
\hline E-336×EV-347 & 9.700EFGHIJ & 4.700FGHIJ & $9.100 \mathrm{O}$ & 71.60JKLMNO & 11.73DEFGHI \\
\hline EV-1097Q×Pop/209 & 9.733 EFGHI & $4.630 \mathrm{HIJ}$ & 9.200 LMNO & $71.30 \mathrm{MNO}$ & 11.70DEFGHI \\
\hline EV-1097Q×B-316 & $10.17 \mathrm{BC}$ & $4.670 \mathrm{GHIJ}$ & $9.670 \mathrm{BCD}$ & 71.53JKLMNO & 11.73DEFGHI \\
\hline EV-1097Q×EV-340 & $10.33 \mathrm{~B}$ & 4.770 FGHI & 9.470 EFGHI & 71.73IJKLM & 11.60 FGHI \\
\hline EV-1097Q×E-322 & $10.13 \mathrm{BC}$ & 4.830 FGH & 9.470 EFGHI & 72.17DEFGH & 11.73DEFGHI \\
\hline EV-1097Q×F-96 & $10.67 \mathrm{~A}$ & 4.830 FGH & $9.630 \mathrm{BCDE}$ & 72.27 DEF & 11.80CDEFGH \\
\hline EV-1097Q×EV-347 & $10.77 \mathrm{~A}$ & $5.130 \mathrm{CD}$ & 9.500DEFGHI & 72.13DEFGHI & 11.83BCDEFGH \\
\hline В-327×Pop/209 & 10.33 B & 5.230 ABCD & 9.400FGHIJK & $72.40 \mathrm{D}$ & $12.00 \mathrm{BCDE}$ \\
\hline B-327×B-316 & $9.800 \mathrm{EFG}$ & 5.270 ABCD & 9.530DEFGH & 72.23DEFG & $12.13 \mathrm{BC}$ \\
\hline B-327×EV-340 & 10.10 BCD & 4.700FGHIJ & 9.430FGHIJ & $72.37 \mathrm{D}$ & 11.93BCDEFG \\
\hline B-327×E-322 & 9.767EFGH & 4.770 FGHI & 9.570 DEFG & $72.37 \mathrm{D}$ & 11.87BCDEFGH \\
\hline B-327×F-96 & $9.833 \mathrm{EF}$ & $4.670 \mathrm{GHIJ}$ & $9.170 \mathrm{MNO}$ & $72.43 \mathrm{D}$ & 11.83BCDEFGH \\
\hline B-327×EV-347 & 9.533HIJKLMN & $4.530 \mathrm{JK}$ & $9.670 \mathrm{BCD}$ & 71.90EFGHIJ & 11.97 BCDEF \\
\hline Raka-poshi×Pop/209 & $9.167 \mathrm{Q}$ & $5.200 \mathrm{ABCD}$ & 9.470EFGHI & $72.33 \mathrm{DE}$ & 11.97 BCDEF \\
\hline Raka-poshi×B-316 & 9.400 LMNOPQ & $5.370 \mathrm{AB}$ & 9.430 FGHIJ & 71.83FGHIJK & 11.73DEFGHI \\
\hline Raka-poshi×EV-340 & 9.500IJKLMNO & $5.330 \mathrm{ABC}$ & 9.170 MNO & 71.77HIJKL & 11.77CDEFGH \\
\hline Raka-poshi×E-322 & 9.667EFGHIJK & 5.170 BCD & 9.200 LMNO & $71.20 \mathrm{O}$ & $11.57 \mathrm{GHI}$ \\
\hline Raka-poshi×F-96 & 9.567GHIJKLM & $5.130 \mathrm{CD}$ & 9.370GHIJKL & 71.37LMNO & $11.50 \mathrm{HIJ}$ \\
\hline Raka-poshi×EV-347 & 9.433KLMNOP & $4.870 \mathrm{FG}$ & 9.430 FGHIJ & $71.17 \mathrm{O}$ & 11.77CDEFGH \\
\hline Sh-139×Pop/209 & 9.467 JKLMNO & $4.630 \mathrm{HIJ}$ & 9.500DEFGHI & $72.27 \mathrm{DEF}$ & 11.67DEFGHI \\
\hline Sh-139×B-316 & $9.267 \mathrm{OPQ}$ & 4.770FGHI & $9.630 \mathrm{BCDE}$ & 71.80GHIJKL & 11.60 FGHI \\
\hline Sh-139×EV-340 & $9.200 \mathrm{PQ}$ & $4.670 \mathrm{GHIJ}$ & 9.500DEFGHI & 71.77HIJKL & 11.73DEFGHI \\
\hline Sh-139×E-322 & 9.200 PQ & 4.770 FGHI & 9.500DEFGHI & 71.70IJKLM & 11.73DEFGHI \\
\hline Sh-139×F-96 & 9.500IJKLMNO & $4.400 \mathrm{KL}$ & $9.170 \mathrm{MNO}$ & 71.50JKLMNO & $11.37 \mathrm{IJ}$ \\
\hline Sh-139×EV-347 & 9.333MNOPQ & 4.870 FG & 9.370GHIJKL & 71.37LMNO & $11.20 \mathrm{~J}$ \\
\hline
\end{tabular}


Table 4a. Statistical significance of parents and $F_{1}$ hybrids of maize for various fodder quality traits

\begin{tabular}{|c|c|c|c|c|c|}
\hline Genotypes & $\begin{array}{l}\text { Acid detergent } \\
\text { fiber \% }\end{array}$ & $\begin{array}{c}\text { Neutrient detergent } \\
\text { fiber } \%\end{array}$ & Fodder cellulose \% & Fodder dry matter \% & $\begin{array}{l}\text { Fodder crude } \\
\quad \text { fiber } \%\end{array}$ \\
\hline Pop/209 & 21.50RST & 51.57MNOP & 30.07 FG & 39.33OPQ & $28.35 \mathrm{CD}$ \\
\hline B-316 & 20.80TUV & 53.43GHIJ & $32.63 \mathrm{C}$ & 40.27GHIJKLM & $27.37 \mathrm{~F}$ \\
\hline EV-340 & 24.00DEFGH & $53.77 \mathrm{GHI}$ & $29.77 \mathrm{GH}$ & $38.93 \mathrm{Q}$ & $27.39 \mathrm{~F}$ \\
\hline E-322 & 24.27BCDE & $55.43 \mathrm{D}$ & 31.13 DE & $38.03 \mathrm{R}$ & $27.27 \mathrm{~F}$ \\
\hline F-96 & 22.60KLMNOPQ & 53.27 HIJ & $30.67 \mathrm{EF}$ & 39.47MNOPQ & $26.26 \mathrm{JK}$ \\
\hline EV-347 & 23.23GHIJKLM & 51.47MNOP & $28.23 \mathrm{I}$ & $38.13 \mathrm{R}$ & $27.89 \mathrm{E}$ \\
\hline B-11 & $25.03 \mathrm{~B}$ & $49.83 \mathrm{RST}$ & $24.80 \mathrm{LM}$ & $39.40 \mathrm{NOPQ}$ & $24.31 \mathrm{QR}$ \\
\hline E-336 & $24.87 \mathrm{BC}$ & $55.50 \mathrm{D}$ & $30.63 \mathrm{EF}$ & 40.00IJKLMNO & $24.10 \mathrm{R}$ \\
\hline EV-1097Q & 24.37 BCDE & $48.83 \mathrm{UV}$ & $24.47 \mathrm{M}$ & 40.87ABCDEFGH & $28.58 \mathrm{C}$ \\
\hline B-327 & 23.37FGHIJKL & $50.77 \mathrm{OPQ}$ & $27.40 \mathrm{IJK}$ & 40.27GHIJKLM & $29.31 \mathrm{~A}$ \\
\hline Raka-poshi & 23.20HIJKLMN & 49.90 QRS & $26.70 \mathrm{~K}$ & 40.00IJKLMNO & $28.99 \mathrm{~B}$ \\
\hline Sh-139 & 23.40FGHIJKL & $48.63 \mathrm{UV}$ & $25.23 \mathrm{LM}$ & 39.90JKLMNOP & 28.38 CD \\
\hline B-11×Pop/209 & 22.20 PQR & 48.90TUV & $26.70 \mathrm{~K}$ & 40.63DEFGHIJ & 24.37 QR \\
\hline B-11×B-316 & 23.40FGHIJKL & $50.57 \mathrm{PQR}$ & $27.17 \mathrm{JK}$ & 39.93JKLMNO & $24.45 \mathrm{Q}$ \\
\hline B-11×EV-340 & $25.03 \mathrm{~B}$ & 51.83 LMN & $26.80 \mathrm{~K}$ & 40.10HIJKLMNO & $25.31 \mathrm{O}$ \\
\hline B-11×E-322 & 22.70KLMNOPQ & $49.43 \mathrm{STU}$ & $26.73 \mathrm{~K}$ & 39.93 JKLMNO & $25.39 \mathrm{NO}$ \\
\hline B-11×F-96 & $22.37 \mathrm{NOPQ}$ & 49.57 STU & $27.20 \mathrm{JK}$ & 39.53 LMNOPQ & $27.12 \mathrm{FG}$ \\
\hline B-11×EV-347 & 24.07 CDEFG & 51.37MNOP & $27.30 \mathrm{JK}$ & $39.33 \mathrm{OPQ}$ & $27.31 \mathrm{~F}$ \\
\hline E-336×Pop/209 & 24.20 CDEF & $51.60 \mathrm{MNO}$ & $27.40 \mathrm{IJK}$ & 40.33 GHIJKL & $27.88 \mathrm{E}$ \\
\hline E-336×B-316 & $24.60 \mathrm{BCD}$ & $54.03 \mathrm{GH}$ & $29.43 \mathrm{GH}$ & 40.53 EFGHIJK & $24.82 \mathrm{P}$ \\
\hline E-336×EV-340 & 22.07 PQRS & $48.73 \mathrm{UV}$ & $26.67 \mathrm{~K}$ & 40.00 IJKLMNO & $24.30 \mathrm{QR}$ \\
\hline E-336×E-322 & $22.30 \mathrm{OPQR}$ & $49.83 \mathrm{RST}$ & 27.53 IJK & 41.00 ABCDEFG & $25.66 \mathrm{MN}$ \\
\hline E-336×F-96 & 24.33 BCDE & $49.80 \mathrm{RST}$ & $25.47 \mathrm{~L}$ & $41.57 \mathrm{AB}$ & $25.89 \mathrm{LM}$ \\
\hline E-336×EV-347 & $26.10 \mathrm{~A}$ & $51.00 \mathrm{NOP}$ & $24.90 \mathrm{LM}$ & 41.20 ABCDEF & $26.28 \mathrm{~J}$ \\
\hline EV-1097Q×Pop/209 & $20.83 \mathrm{TUV}$ & $52.27 \mathrm{KLM}$ & $31.43 \mathrm{DE}$ & $41.67 \mathrm{~A}$ & $27.42 \mathrm{~F}$ \\
\hline EV-1097Q×B-316 & 22.10 PQRS & 53.53GHIJ & 31.43 DE & 40.87ABCDEFGH & $27.36 \mathrm{~F}$ \\
\hline EV-1097Q×EV-340 & 22.87JKLMNOPQ & $56.83 \mathrm{C}$ & $33.97 \mathrm{~B}$ & 40.63DEFGHIJ & $27.36 \mathrm{~F}$ \\
\hline EV-1097Q×E-322 & 22.47 MNOPQ & $58.87 \mathrm{~A}$ & $36.43 \mathrm{~A}$ & 41.40ABCD & $28.33 \mathrm{CD}$ \\
\hline EV-1097Q $\times F-96$ & 23.63 EFGHIJ & $57.97 \mathrm{~B}$ & $34.33 \mathrm{~B}$ & 41.33 ABCDE & $28.40 \mathrm{CD}$ \\
\hline EV-1097Q×EV-347 & $22.37 \mathrm{NOPQ}$ & $55.00 \mathrm{DEF}$ & $32.63 \mathrm{C}$ & 41.33 ABCDE & 28.12 DE \\
\hline B-327×Pop/209 & $21.50 \mathrm{RST}$ & $48.30 \mathrm{~V}$ & $26.80 \mathrm{~K}$ & 40.70CDEFGHIJ & $27.30 \mathrm{~F}$ \\
\hline B-327×B-316 & 23.13IJKLMNO & 51.03 NOP & $27.90 \mathrm{IJ}$ & 40.30GHIJKLM & $27.35 \mathrm{~F}$ \\
\hline B-327×EV-340 & 22.13 PQRS & $55.67 \mathrm{D}$ & $33.53 \mathrm{~B}$ & 40.00 IJKLMNO & $27.27 \mathrm{~F}$ \\
\hline B-327×E-322 & 22.90 JKLMNOP & $40.10 \mathrm{Y}$ & $17.20 \mathrm{O}$ & 39.97 JKLMNO & $26.89 \mathrm{GH}$ \\
\hline B-327×F-96 & 20.63 UVW & $43.60 \mathrm{X}$ & $22.97 \mathrm{~N}$ & $39.33 \mathrm{OPQ}$ & $25.42 \mathrm{NO}$ \\
\hline B-327×EV-347 & $21.00 \mathrm{TUV}$ & $45.40 \mathrm{~W}$ & $24.40 \mathrm{M}$ & 39.47 MNOPQ & $25.31 \mathrm{O}$ \\
\hline Raka-poshi×Pop/209 & $20.37 \mathrm{VW}$ & $45.03 \mathrm{~W}$ & $24.67 \mathrm{LM}$ & 39.47 MNOPQ & $25.95 \mathrm{KLM}$ \\
\hline Raka-poshi×B-316 & 22.03 QRS & $52.07 \mathrm{KLM}$ & $30.03 \mathrm{FG}$ & $39.10 \mathrm{PQ}$ & $26.19 \mathrm{JKL}$ \\
\hline Raka-poshi×EV-340 & 22.57 LMNOPQ & $53.63 \mathrm{GHI}$ & 31.07 DE & 40.00 IJKLMNO & $26.41 \mathrm{IJ}$ \\
\hline Raka-poshi×E-322 & 22.03 QRS & 52.97 IJK & $30.93 \mathrm{DE}$ & 40.30 GHIJKLM & $26.43 \mathrm{IJ}$ \\
\hline Raka-poshi×F-96 & $19.97 \mathrm{~W}$ & 51.43 MNOP & 31.47 DE & 40.83BCDEFGHI & $26.69 \mathrm{HI}$ \\
\hline Raka-poshi×EV-347 & $21.33 \mathrm{STU}$ & $52.60 \mathrm{JKL}$ & 31.27 DE & 41.33ABCDE & $26.46 \mathrm{IJ}$ \\
\hline Sh-139×Pop/209 & 23.43 FGHIJK & 54.27 FG & $30.83 \mathrm{EF}$ & 41.47 ABC & $27.91 \mathrm{E}$ \\
\hline Sh-139×B-316 & 24.20 CDEF & $55.30 \mathrm{DE}$ & $31.10 \mathrm{DE}$ & 40.47FGHIJK & $27.21 \mathrm{~F}$ \\
\hline Sh-139×EV-340 & 23.87 DEFGHI & $55.67 \mathrm{D}$ & $31.80 \mathrm{D}$ & 39.90JKLMNOP & $27.36 \mathrm{~F}$ \\
\hline Sh-139×E-322 & $22.40 \mathrm{MNOPQ}$ & 51.47 MNOP & $29.07 \mathrm{H}$ & 40.20GHIJKLMN & $27.84 \mathrm{E}$ \\
\hline Sh-139×F-96 & 23.40 FGHIJKL & 54.37 EFG & $30.97 \mathrm{DE}$ & 39.70KLMNOPQ & $28.13 \mathrm{DE}$ \\
\hline Sh-139×EV-347 & $24.00 \mathrm{DEFGH}$ & $54.97 \mathrm{DEF}$ & $30.97 \mathrm{DE}$ & 40.10HIJKLMNO & $28.50 \mathrm{C}$ \\
\hline
\end{tabular}


Table 4b.Statistical significance of parents and $F_{1}$ hybrids of maize for various fodder quality traits

\begin{tabular}{|c|c|c|c|c|c|}
\hline Genotypes & $\begin{array}{l}\text { Fodder crude } \\
\text { protein } \%\end{array}$ & Fodder moisture \% & $\begin{array}{l}\text { Fodder ether } \\
\text { extractable fat \% }\end{array}$ & $\begin{array}{c}\text { Fodder nitrogen free } \\
\text { extract } \\
\text { (Carbohydrate \%) }\end{array}$ & Fodder ash \% \\
\hline Pop/209 & 9.630OPQ & 9.190BCDE & 2.867IJKL & 41.36JKLMNO & 8.600MNOPQ \\
\hline B-316 & $8.970 \mathrm{~S}$ & $8.150 \mathrm{P}$ & 2.903EFGHIJK & $43.46 \mathrm{BC}$ & 9.130HIJK \\
\hline EV-340 & $9.770 \mathrm{NOP}$ & 9.120GHIJ & 2.950BCDEFGHI & 41.63HIJKLMN & 9.140GHIJK \\
\hline E-322 & $11.81 \mathrm{CD}$ & $9.090 \mathrm{IJ}$ & $3.000 \mathrm{BCD}$ & 39.89 QRS & 8.930JKLM \\
\hline F-96 & $11.01 \mathrm{IJ}$ & $9.090 \mathrm{IJ}$ & $3.103 \mathrm{~A}$ & 41.78GHIJKLM & 8.760 LMNO \\
\hline EV-347 & $11.81 \mathrm{CD}$ & 9.120GHIJ & 2.917DEFGHIJK & 39.56 RS & $8.700 \mathrm{MNO}$ \\
\hline B-11 & $11.01 \mathrm{IJ}$ & 9.160DEFG & 2.940BCDEFGHI & $43.31 \mathrm{BCDE}$ & 9.270 FGHI \\
\hline E-336 & $9.480 \mathrm{PQ}$ & $9.240 \mathrm{~A}$ & 2.810 LMNO & $46.11 \mathrm{~A}$ & 8.270QRSTU \\
\hline EV-1097Q & 9.630OPQ & 9.200ABCD & $2.747 \mathrm{OP}$ & 40.69MNOPQR & 9.170FGHIJ \\
\hline B-327 & $9.770 \mathrm{NOP}$ & $9.240 \mathrm{~A}$ & $2.710 \mathrm{P}$ & $40.34 \mathrm{OPQR}$ & 8.630 MNOP \\
\hline Raka-poshi & $13.20 \mathrm{~A}$ & 9.170CDEF & 2.753 NOP & $37.84 \mathrm{~T}$ & $8.060 \mathrm{U}$ \\
\hline Sh-139 & $12.69 \mathrm{~B}$ & 9.140FGH & $2.840 \mathrm{KLM}$ & 38.84 ST & $8.110 \mathrm{TU}$ \\
\hline B-11×Pop/209 & $8.820 \mathrm{ST}$ & $8.790 \mathrm{O}$ & 2.880 GHIJKL & $46.28 \mathrm{~A}$ & 8.850 KLMN \\
\hline B-11×B-316 & $11.81 \mathrm{CD}$ & $8.920 \mathrm{~N}$ & 2.877 HIJKL & 43.18BCDEF & 8.770 LMNO \\
\hline B-11×EV-340 & 11.31FGHI & $8.950 \mathrm{MN}$ & 2.933CDEFGHIJ & 41.59HIJKLMNO & $9.910 \mathrm{~B}$ \\
\hline B-11×E-322 & $10.87 \mathrm{JK}$ & 9.160DEFG & 2.963BCDEFGH & 40.46 NOPQR & $11.17 \mathrm{~A}$ \\
\hline B-11×F-96 & 11.66CDE & 9.200ABCD & $2.727 \mathrm{OP}$ & 41.15 KLMNOP & $8.140 \mathrm{TU}$ \\
\hline B-11×EV-347 & $11.01 \mathrm{IJ}$ & 9.200ABCD & $2.870 \mathrm{IJKL}$ & 41.55IJKLMNO & $8.050 \mathrm{U}$ \\
\hline E-336×Pop/209 & $12.69 \mathrm{~B}$ & 9.150EFGH & $3.000 \mathrm{BCD}$ & $39.11 \mathrm{~S}$ & $8.170 \mathrm{STU}$ \\
\hline E-336×B-316 & 11.23GHI & 9.090IJ & $2.980 \mathrm{BCDE}$ & $43.70 \mathrm{~B}$ & 8.190 RSTU \\
\hline E-336 $\times$ EV -340 & $8.820 \mathrm{ST}$ & 9.200ABCD & $2.980 \mathrm{BCDE}$ & $46.18 \mathrm{~A}$ & 8.510 OPQR \\
\hline E-336 $\times$ E-322 & $11.96 \mathrm{C}$ & $9.220 \mathrm{AB}$ & 2.957BCDEFGHI & 41.60HIJKLMNO & 8.610 MNOP \\
\hline E-336×F-96 & $11.09 \mathrm{HIJ}$ & $9.240 \mathrm{~A}$ & 2.933CDEFGHIJ & 41.18KLMNOP & $9.660 \mathrm{BCD}$ \\
\hline E-336×EV-347 & 11.52DEFG & $8.970 \mathrm{M}$ & 2.930CDEFGHIJ & 40.68 MNOPQR & 9.630BCDE \\
\hline EV-1097Q×Pop/209 & $11.74 \mathrm{CD}$ & $8.910 \mathrm{~N}$ & 2.943BCDEFGHI & $39.66 \mathrm{RS}$ & 9.330EFGHI \\
\hline EV-1097Q×B-316 & 11.38EFGH & $9.030 \mathrm{~L}$ & 2.887 FGHIJKL & 39.96 PQRS & 9.400DEFGH \\
\hline EV-1097Q×EV-340 & $11.59 \mathrm{DEF}$ & $9.040 \mathrm{KL}$ & 2.810 LMNO & $39.71 \mathrm{RS}$ & $9.490 \mathrm{CDEF}$ \\
\hline EV-1097Q ×E-322 & $8.970 \mathrm{~S}$ & $9.030 \mathrm{~L}$ & 2.837 KLMN & 41.04LMNOPQ & $9.800 \mathrm{BC}$ \\
\hline EV-1097Q ×F-96 & $9.340 \mathrm{QR}$ & $9.080 \mathrm{JK}$ & $2.847 \mathrm{JKL}$ & 40.65MNOPQR & $9.690 \mathrm{BCD}$ \\
\hline EV-1097Q×EV-347 & $7.730 \mathrm{U}$ & $9.110 \mathrm{HIJ}$ & 2.757 MNOP & 43.00BCDEFG & 9.270 FGHI \\
\hline В-327×Pop/209 & $9.630 \mathrm{OPQ}$ & 9.120GHIJ & 2.763 MNOP & 42.63BCDEFGHI & $8.570 \mathrm{NOPQ}$ \\
\hline B-327×B-316 & $10.06 \mathrm{MN}$ & 9.130FGHI & 2.763 MNOP & 42.34CDEFGHIJK & 8.350PQRSTU \\
\hline B-327×EV-340 & $8.530 \mathrm{~T}$ & $9.210 \mathrm{ABC}$ & 2.757 MNOP & 42.83BCDEFGH & 9.410DEFGH \\
\hline B-327×E-322 & $8.830 \mathrm{ST}$ & 9.190BCDE & 2.940BCDEFGHI & 42.72BCDEFGHI & 9.440DEFGH \\
\hline B-327×F-96 & $7.810 \mathrm{U}$ & 9.160DEFG & $3.017 \mathrm{BC}$ & $46.28 \mathrm{~A}$ & 8.330PQRSTU \\
\hline B-327×EV-347 & $11.01 \mathrm{IJ}$ & 9.170CDEF & $3.027 \mathrm{~B}$ & 42.01FGHIJKL & 9.470 DEFG \\
\hline Raka-poshi×Pop/209 & $9.630 \mathrm{OPQ}$ & $9.040 \mathrm{KL}$ & $2.990 \mathrm{BCDE}$ & 43.03BCDEFG & 9.370DEFGHI \\
\hline Raka-poshi×B-316 & $9.700 \mathrm{OP}$ & $9.040 \mathrm{KL}$ & 2.980 BCDE & $43.34 \mathrm{BCD}$ & 8.750LMNO \\
\hline Raka-poshi×EV-340 & $9.840 \mathrm{MNO}$ & 9.120GHIJ & 2.980 BCDE & 43.04BCDEFG & 8.610 MNOP \\
\hline Raka-poshi×E-322 & $9.910 \mathrm{MNO}$ & $9.110 \mathrm{HIJ}$ & 2.973 BCDEF & 42.94BCDEFG & 8.630 MNOP \\
\hline Raka-poshi×F-96 & $10.65 \mathrm{KL}$ & 9.130FGHI & 2.950BCDEFGHI & 42.08DEFGHIJKL & 8.500OPQRS \\
\hline Raka-poshi×EV-347 & $10.53 \mathrm{~L}$ & $9.140 \mathrm{FGH}$ & 2.930CDEFGHIJ & $39.79 \mathrm{RS}$ & 8.480 OPQRS \\
\hline Sh-139×Pop/209 & $11.01 \mathrm{IJ}$ & 9.120GHIJ & 2.950BCDEFGHI & 40.57 MNOPQR & 8.430OPQRST \\
\hline Sh-139×B-316 & $10.13 \mathrm{M}$ & 9.130FGHI & $3.007 \mathrm{BCD}$ & 42.05EFGHIJKL & 8.470 OPQRS \\
\hline Sh-139×EV-340 & $9.700 \mathrm{OP}$ & $9.140 \mathrm{FGH}$ & 2.993 BCDE & 42.22CDEFGHIJKL & $8.600 \mathrm{MNOPQ}$ \\
\hline Sh-139×E-322 & $9.630 \mathrm{OPQ}$ & 9.160DEFG & 2.953BCDEFGHI & 41.36 JKLMNO & $9.060 \mathrm{IJKL}$ \\
\hline Sh-139×F-96 & $9.040 \mathrm{RS}$ & 9.130FGHI & $2.870 \mathrm{IJKL}$ & 42.55BCDEFGHIJ & $8.180 \mathrm{RSTU}$ \\
\hline Sh-139×EV-347 & $8.970 \mathrm{~S}$ & $9.150 \mathrm{EFGH}$ & 2.970 BCDEFG & 41.14 KLMNOP & 9.270 FGHI \\
\hline
\end{tabular}

It was suggested from results given in Table 3 that significant differences were found for grain protein percentage. The results also indicated that higher additive variance for male $\times$ female interaction was found for fodder crude fiber, fodder nitrogen free extract (carbohydrates), acid detergent fiber, nutrient detergent fiber and fodder cellulose while lowest for fodder moisture percentage and ether extractable fat. Higher female additive variance as reported for acid detergent fiber, fodder crude fiber, nutrient detergent fiber and fodder cellulose while lowest for grain crude fiber, fodder moisture percentage and ether extractable fat. Higher male additive variance was found for acid detergent fiber, nutrient detergent fiber and fodder ash percentage. The higher cumulative additive effect was recorded for acid detergent fiber, fodder crude fiber, nutrient detergent fiber and fodder cellulose while lowest for grain crude fiber, fodder moisture percentage and ether extractable fat but higher dominance effect was recorded for grain starch percentage, acid detergent fiber, fodder crude fiber, nutrient detergent fiber, fodder dry matter, fodder ash, fodder crude fiber and fodder cellulose while lowest was recorded for fodder moisture percentage and ether extractable fat. The highest degree of dominance was recorded for grain crude fiber, fodder crude fiber and fodder ash percentage while lowest was for fodder 
nitrogen free extract. Higher values of dominance effect and degree of dominance indicated that over type of dominance gene action was shown for grain and fodder quality traits. The over dominance and higher degree of dominance indicated that selection on the basis of grain and fodder quality may be helpful for the development of hybrid seed with better grain and fodder quality [39-42].

\subsection{Principle Component Bi-plot Analysis}

It was suggested from principle component bi-plot 1 that the inbred lines B-11, B-336, Sh-139 and EV-1097 and $\mathrm{F}_{1}$ hybrids B-11×EV-347, B-336×Pop/209, B-336×B316, B-336 $\times$ E-322 and Sh-139 $\times$ F-96 performed well for grain oil percentage, grain crude protein percentage, grain starch percentage and embryo percentage. The performance of B-11, B-11 $\times \mathrm{EV}-347, \mathrm{EV}-1097 \times \mathrm{E}-322$, Sh-139 $\times$ B-316, B-327 $\times$ E-322 and Sh-139 $\times$ F-96 was higher for ether extractable fat percentage, ash percentage, fodder cellulose percentage, fodder crude fiber percentage and acid detergent percentage (principle component biplot 2) while B-316, Raka-poshi, B-11 $\times$ Pop/209, B336 $\times$ EV-340, B-327×E-322, B-327×F-96, EV-1097×E322, Raka-poshi $\times E V-347, E V-1097 \times$ Pop/209 and EV$1097 \times \mathrm{EV}-340$ performed better for fodder moisture percentage, nitrogen free extract percentage (carbohydrates \%), nutrient detergent fiber percentage, fodder crude protein percentage and fodder dry matter percentage (principle component bi-plot 3). It was concluded from principle component bi-plot analysis that the accessions that performed better for all grain and fodder quality traits may be used for the development of good quality maize hybrids and synthetic varieties to improve maize yield and production. Results were in favor of the finds reported by $[11,20,21,43]$.

\section{Conclusions}

From prescribed study, it was reported from results that higher heritability, genetic advance, significant genotypic and phenotypic correlation and cumulative additive effect for grain protein percentage, grain oil percentage, grain starch percentage, nutrient detergent fiber, fodder cellulose, fodder crude fiber, fodder crude protein and fodder moisture percentage suggested that selections may be made to develop synthetic varieties for better quality but higher dominance effect and degree of dominance indicated that selection may be useful for the development of good quality maize hybrids through heterosis breeding program. Principle component bi-plot analysis indicated that B-11 $\times$ EV-347, B-11, Sh-139, EV-1097 $\times$ E-322, Sh$139 \times$ B-316, B-327 $\times$ E-322, B-316, Raka-poshi, B$11 \times$ Pop/209, B-336 $\times$ EV-340, B-327×E-322, B-327×F-96, EV-1097×E-322, Raka-poshi $\times$ EV-347, EV-1097×Pop/209 and EV-1097 $\times E V-340$ performed better for grain and fodder quality and may be used for improvement of grain and fodder quality of maize .
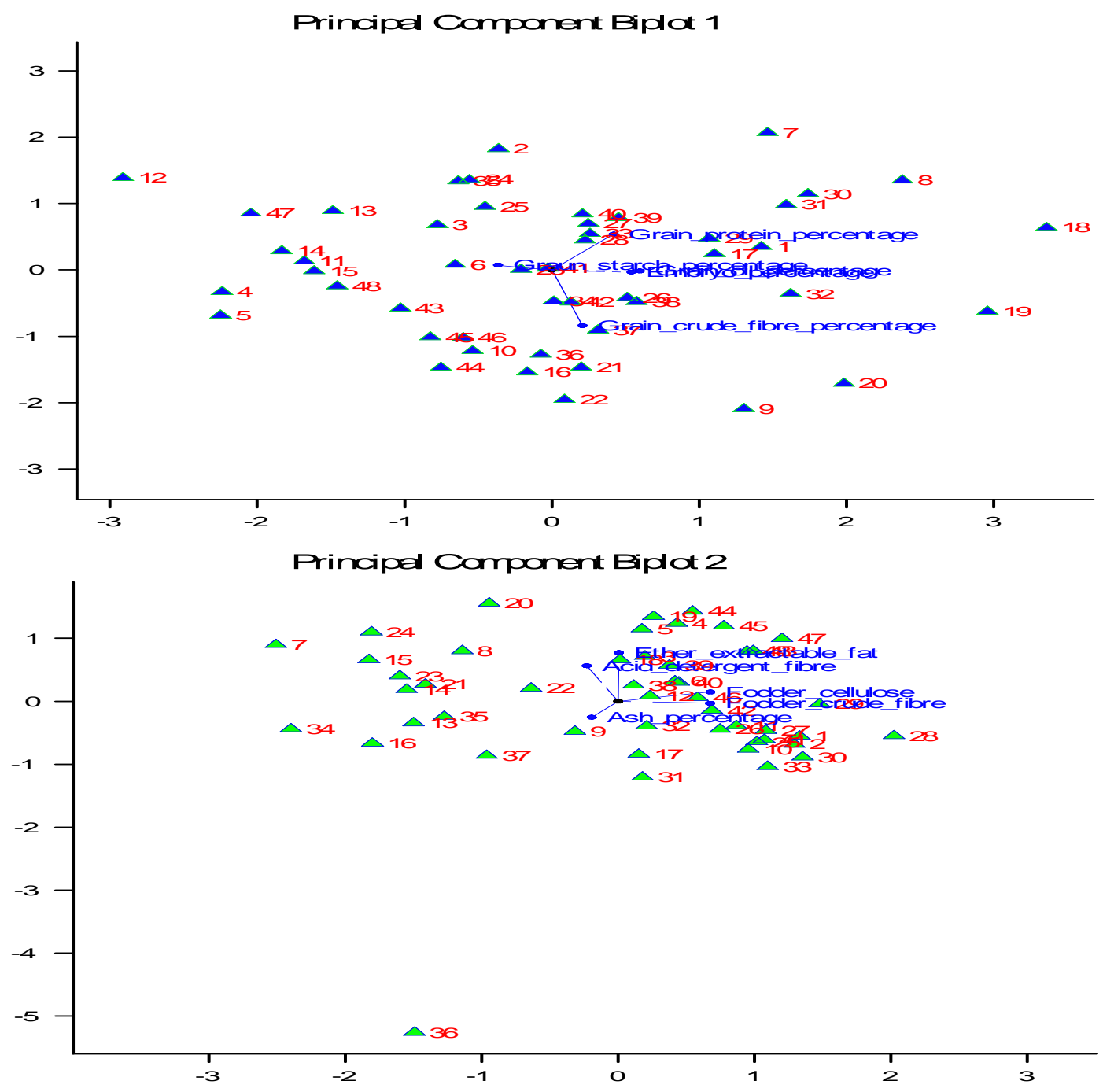


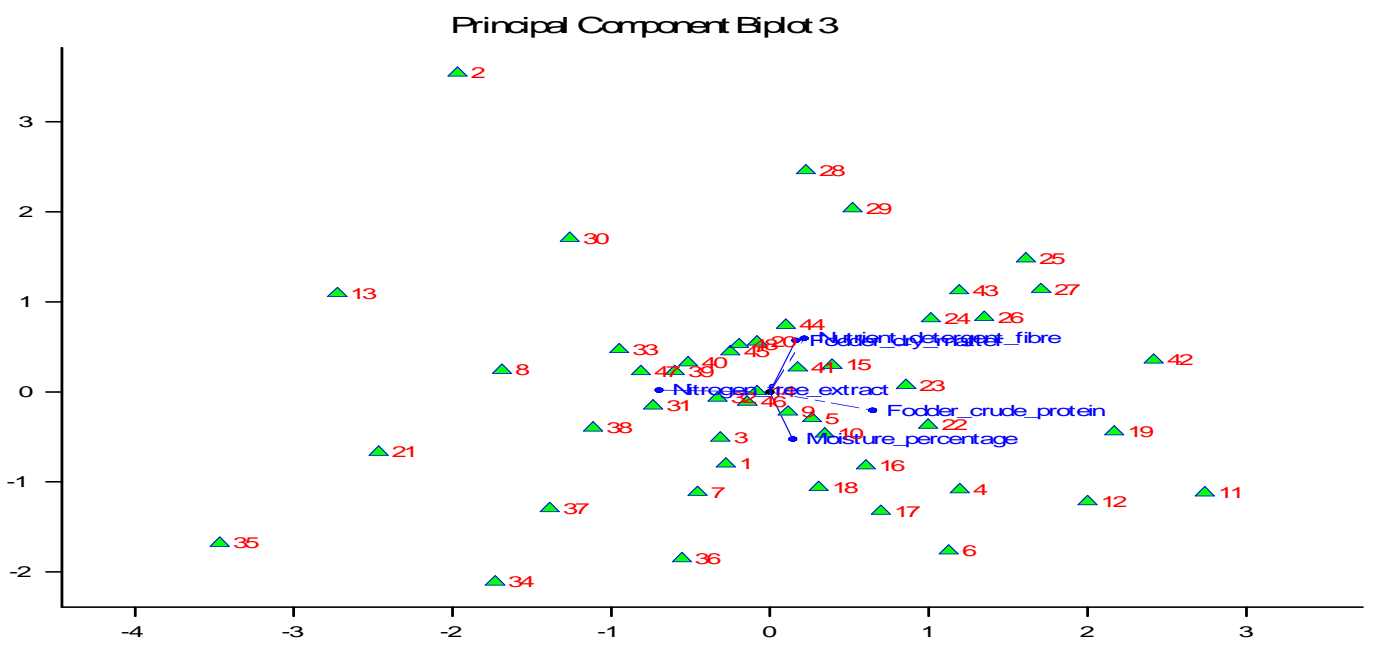

\section{Acknowledgment}

We are thankful to Higher Education Commission of Pakistan supporting us for this research.

\section{Conflict of Interest}

Authors have shown no conflict of interest.

\section{References}

[1] Maddon PJ, Littman DR, Godfrey M, Maddon DE, Chess L. "The isolation and nucleotide sequence of a cDNA encoding the T cell surface protein T4: a new member of the immunoglobulin gene family”. Cell, 42 (1). 93-104, Aug, 1985.

[2] Dost M. "The Introduction and Use of Oat (Avena sativa) Cultivars In Pakistan”. Aga Khan Rural Support Program (AKRSP) Gilgit Pakistan, 1970.

[3] Asghar A, Ali A, Syed W, Asif M, Khaliq T. "Growth and yield of maize (Zea mays L.) cultivars affected by NPK application in different proportion”. Pakistan J Sci, 62 (4). 211-215, Dec, 2010.

[4] Yousuf M, Saleem M. "Correlation analysis of S1 families of maize for grain yield and its components". Int J Agric Biol, 4 (3). 387-388, Aug, 2001.

[5] Younas M, Yaqoob M. "Feed resources of livestock in the Punjab, Pakistan". Livestock Research for Rural Development, 17 (2). 2005, Feb, 2005.

[6] Rashid M, Ranjha AM, Rehim A. "Model based P fertilization to improve yield and quality of sorghum (Sorghum bicolor L.) fodder on an ustochrept soil”. Pak J Agri Sci, 44 (2). 221-227, jun, 2007.

[7] Ali Q, Ahsan M, Tahir MHN, Basra SMA. "Genetic evaluation of maize (Zea mays L.) accessions for growth related seedling traits". International Journal for Agro Veterinary and Medical Sciences, 6 (3). 164-172, Feb, 2012.

[8] Farooq J, Khaliq I, Kashif M, Ali Q, Mahpara S. "Análisis Genético del Porcentaje Relativo de Daño celular y algún Rasgo que Contribuye al Rendimiento en Trigo bajo Condiciones Normales y de Estrés Térmico”. Chilean journal of agricultural research, 71 (4). 511-520, month, 2011.

[9] Hussain B, Khan MA, Ali Q, dab Shaukat S. "Double Haploid Production is the Best Method for Genetic Improvement and Genetic Studies of Wheat”. International Journal for Agro Veterinary and Medical Sciences, 6 (4). 216-228, Sep, 2012.

[10] Hussain B, Khan MA, Ali Q, dab Shaukat S. "Double Haploid Production in Wheat through Microspo re Culture and Wheat X Maize Crossing System: An Over view”. International Journal for Agro Veterinary and Medical Sciences, 6 (5). 332-344, Sep, 2012.

[11] Khalil I, Shah H, Yasmeen F, Mumtaz M. "Seed yield and fatty acid profile of sunflower hybrids". Sarhad Journal of Agriculture, 16 (6). 601-604, Dec, 2000.

[12] Kwon S, Torrie J. "Heritability and interrelationship among traits of two soybean populations”. Crop Sci, 4 (2). 196-198, Dec, 1964.
[13] Sun W-H, Liu X-Y, Wang Y, Hua Q, Song XM. "Effect of water stress on yield and nutrition quality of tomato plant over expressing StAPX”. Biologia Plantarum, 58 (1). 99-104, jun, 2014.

[14] Naveed MT, Ali Q, Ahsan M, Hussain B. "Correlation and path coefficient analysis for various quantitative traits in chickpea (Cicer arietinum L.)". International Journal for Agro Veterinary and Medical Sciences, 6 (2). 97-106, Jan, 2012.

[15] Ali Q, Ahsan M, Tahir MHN, Basra SMA. "Genetic studies of morpho-physiological traits of maize (Zea mays L.) seedling”. African Journal of Agricultural Research, 8 (28). 3668-3678, Jul, 2013.

[16] Van Soest Pv, Robertson J, Lewis B. "Methods for dietary fiber, neutral detergent fiber, and nonstarch polysaccharides in relation to animal nutrition”. Journal of dairy science, 74 (10). 3583-3597, Oct, 1991.

[17] Valsta LM, Kilkkinen A, Mazur W, Nurmi T, Lampi AM. "Phytooestrogen database of foods and average intake in Finland" British Journal of Nutrition, 89 (S1). S31-S38, Oct, 2003.

[18] Dubey R, Joshi V, Verma M. "Heterosis for nutritional quality and yield in conventional and nonconventional hybrids of maize (Zea mays L.)”. Indian Journal of Genetics and Plant Breeding, 69 (2). 109-114, Feb, 2009.

[19] Duvick DN. "The Contribution of Breeding to Yield Advances in maize (Zea mays L.)”. Advances in agronomy, 8683-145, May, 2005.

[20] Xiang K, Yang K, Pan G, Reid L, Li W. "Genetic diversity and classification of maize landraces from China's Sichuan Basin based on agronomic traits, quality traits, combining ability and SSR markers”. Maydica, 55 (1). 85, Jul, 2010.

[21] Awan TH, Mahmood MT, Maqsood M, Usman M, Hussain MI. "Studies on hybrid and synthetic cultivars of maize for forage yield and quality”. Pak J Agri SCi Vol, 381-2, Jun, 2001.

[22] Sanderson MA, Adler PR. "Perennial forages as second generation bioenergy crops”. International Journal of Molecular Sciences, 9 (5). 768-788, May, 2008.

[23] Jat R, Ahlawat I. "Effect of vermicompost, biofertilizer and phosphorus on growth, yield and nutrient uptake by gram (Cicer arietinum) and their residual effect on fodder maize (Zea mays)". Indian journal of agricultural science, 74 (7). 359-361, Sep, 2004.

[24] Suthar M, Singh D, Nepalia V, Singh A. "Performance of sweet corn (Zea mays) varieties under varying fertility levels". Indian Journal of Agronomy, 59 (1). 168-170, May, 2014.

[25] Bertalot MJ, Guerrini IA, Mendoza E, Pinto MS. "Productivity, Leaf Nutrient Content and Soil Carbon Stocked in Agroforestry and Traditional Management of Maize (Zea mays L.)”. American Journal of Plant Sciences, 5 (06). 884, Mar, 2014.

[26] Kumawat P, Kaushik M, Singh D, Kumawat K. "Yield, nutrient content, uptake and quality of sweet corn varieties as influenced by nitrogen and phosphorus fertilization under Southern Rajasthan condition”. Annals of Agri Bio Research, 19 (1). 67-69, Mar, 2014

[27] Ali A, Muzaffar A, Awan MF, ud Din S, Nasir IA. "Genetically Modified Foods: Engineered tomato with extra advantages”. Advancements in Life Sciences, 1 (3). 139-152, May, 2014.

[28] Sonawane R, Dandge M, Kamble A, Shingrup P. "Effect of herbicides on nutrient uptake and yield of Kharif maize (Zea mays L.)”. BIOINFOLET-A Quarterly Journal of Life Sciences, 11 (1a). 136-138, Aug, 2014. 
[29] Chaudhary D, Jat S, Kumar R, Kumar A, Kumar B (2014) Fodder Quality of Maize: Its Preservation. Maize: Nutrition Dynamics and Novel Uses: Springer. pp. 153-160.

[30] Khan S, Anwar K, Kalim K, Saeed A, Shah SZ. "Nutritional Evaluation of Some Top Fodder Tree Leaves and Shrubs of District Dir (Lower), Pakistan as a quality livestock feed". Int $J$ Curr Microbiol App Sci, 3 (5). 941-947, Mar, 2014.

[31] Nazli RI, Kuşvuran A, Inal I, DemirbaŞ A, Tansi V. "Effects of different organic materials on forage yield and quality of silage maize (Zea mays L.)". Turkish Journal of Agriculture and Forestry, 38 (1). 23-31, Dec, 2014.

[32] Geta T, Nigatu L, Animut G. "Evaluation of Potential Yield and Chemical Composition of Selected Indigenous Multi-Purpose Fodder Trees in Three Districts of Wolayta Zone, Southern Ethiopia”. World Applied Sciences Journal, 31 (3). 399-405, Mar, 2014.

[33] Cocaliadis MF, Fernández-Muñoz R, Pons C, Orzaez D, Granell A. "Increasing tomato fruit quality by enhancing fruit chloroplast function. A double-edged sword?”. Journal of experimental botany, eru 165, Apr, 2014.

[34] Asaduzzaman M, Biswas M, Islam MN, Rahman MM, Begum R. "Variety and N-Fertilizer Rate Influence the Growth, Yield and Yield Parameters of Baby Corn (Zea mays L.)”. Journal of Agricultural Science, 6 (3). P 118, Sep, 2014.

[35] Amodu J, Akpensuen T, Dung D, Tanko R, Musa A. "Evaluation of Maize Accessions for Nutrients Composition, Forage and Silage Yields”. Journal of Agricultural Science, 6 (4). p178, Mar, 2014.
[36] Bibi A, Sadaqat HA, Ali Q. “Combining ability analysis for green forage associated traits in sorghum-sudangrass hybrids under water stress". International Journal for Agro Veterinary and Medical Sciences, 6 (2). 115-137, Jan, 2012.

[37] Zhu X, Richael C, Chamberlain P, Busse JS, Bussan AJ. "Vacuolar Invertase Gene Silencing in Potato (Solanum tuberosum L.) Improves Processing Quality by Decreasing the Frequency of Sugar-End Defects”. PloS one, 9 (4). e93381, Apr, 2014.

[38] Mok H-F, Dassanayake KB, Hepworth G, Hamilton AJ. "Field comparison and crop production modeling of sweet corn and silage maize (Zea mays L.) with treated urban wastewater and freshwater”. Irrigation Science, 1-18, Mar, 2014.

[39] Welcker C, Andréau B, De Leon C, Parentoni S, Bernal J. "Heterosis and combining ability for maize adaptation to tropical acid soils”. Crop science, 45 (6). 2405-2413, Oct, 2005.

[40] Akbar M, Saleem M, Ashraf MY, Husain A, Azhar F. “Combining ability studies for physiological and grain yield traits in maize at two temperature regimes”. Pak J Bot, 41 (4). 1817-1829, jul, 2009.

[41] Akbar M, Saleem M, Azhar F, Ashraf MY, Ahmad R. "Combining ability analysis in maize under normal and high temperature conditions”. J Agric Res, 46 (1). 261-277, Aug, 2008.

[42] Wali M, Kachapur R, Chandrashekhar C, Kulkarni V, Devaranavadagi S. "Gene action and combining ability studies in single cross hybrids of maize (Zea mays L.)”. Karnataka Journal of Agricultural Sciences, 23 (4), Feb, 2010.

[43] Saleem M, Ahsan M, Aslam M, Majeed A. "Comparative evaluation and correlation estimates for grain yield and quality attributes in maize”. Pak J Bot, 40 (6). 2361-2367, Feb, 2008. 